\title{
Ideología y Prensa Escrita: la Guerra Cristera en la Prensa Vasca
}

\author{
Maricruz Castro Ricalde \\ Departamento de Comunicación y Humanidades-ITESM
}

\begin{abstract}
Resumen: El objetivo del presente trabajo es describir de qué manera fue dada a conocer la guerra cristera mexicana en la prensa del País Vasco. Para ello hemos escogido dos medios impresos que representan dos tendencias ideológicas distintas: El Liberal y La Gaceta del Norte, los cuales eran los de mayor circulación en la segunda década de este siglo en esa región. Mediante el análisis de los contenidos y de sus características formales no sólo ratificamos la tendencia ideológica de las publicaciones, sino también la caracterización que se conforma sobre los protagonistas de los sucesos, a partir de la ideología sostenida por cada medio; el grado de interés que un hecho tan lejano geográficamente despertó en la prensa vasca y los posibles motivos para que así ocurriera.

Abstract: This article aims to describe how the Basque Country newspaper press spread a piece of news about the Mexican Christian War. We have chosen two newspapers, which represent two different ideologic trends: El Liberal and La Gaceta del Norte. Both of them were the most sold journals, in the second decade of this century, in that region. Due to the content and formal analysis, we ratify the ideologic trend of those newspapers, how they characterize each protagonist of the Mexican Christian War, depending on the media's ideology; how much that war was important to the press, despite of the distance between Spain and Mexico and, finally, the possible reasons because Mexican Christian War was atractive to the Basque Country newspaper press.
\end{abstract}

\section{Introducción}

1 objetivo del presente trabajo es observar de qué manera fue dada a conocer la guerra cristera mexicana en la prensa vasca. Partimos del supuesto de que toda producción textual está modelada por los diversos aspectos contextuales que han permitido su surgimiento y su difusión. Los diarios vascos no son la excepción, y dadas las particularidades de cada medio, los textos publicados se convierten en su plataforma de proyección ideológica.

Si nos detenemos en la vastedad de títulos registrados en los anales del periodismo vasco de principios de siglo, podemos intuir la trascendencia que tenía la prensa escrita en la comunidad lectora de esa región. No sólo se detecta un gran número de periódicos, sino que el espectro ideológico que cubren es también muy amplio. Sin embargo, 
según la vida política del Estado español se iba agitando a lo largo de la segunda década de esta centuria, los medios de comunicación escritos mostraban también una mayor radicalidad en la forma como daban a conocer la información a sus lectores. El análisis de este tipo de impresos, de aquellos que dan cuenta de las diferentes tendencias que prevalecían en un momento determinado de la vida de una comunidad se torna importante, si nuestro objetivo es detectar quién ve qué acontecimiento y desde qué perspectiva.

Un medio de comunicación puede declarar abiertamente cuál es su postura ideológica. Lo puede explicitar, por ejemplo, en su subtítulo, el editorial de apertura, su logotipo e incluso, en el mismo título, en el caso de la prensa escrita. De aquí que no es anómalo deducir que la selección y el tratamiento de la información publicada está de acuerdo con el pensamiento directriz del medio. No importa que dicha información no sea de naturaleza estrictamente local, ya que también lo acaecido en otras partes del mundo es visto con los mismos ojos marcados por la ideología que prevalece en la publicación. De esta forma, todos los textos que se dan a conocer en los diarios pueden ser vistos como puntales de una plataforma ideológica, a la que pretenden adherir al público lector o bien, emplearla como elemento ratificador para los receptores que ya comparten ese punto de vista (Castro; 1998: 49).

Este tipo de trabajos, entonces, pretende confrontar la tesis ampliamente aceptada de que la información se establece a partir de hechos y no de ideas. A los primeros les corresponde el campo de la realidad, lo externo, lo verificable y universal; a las segundas, lo imaginario, el mundo interior, lo valorativo e individual. Así, sustantivos como "neutralidad", "objetividad" o "imparcialidad" ratifican la dicotomía hechos/ideas y, de esta forma, las ideas pueden ser disfrazadas, dado que al hablarse de datos, de acontecimientos que sí tuvieron lugar, éstos deben ser aceptados sin cuestionamiento ni crítica alguna. En el análisis de nuestra muestra, demostraremos cómo existen elementos de contenido y formales que permiten al medio de comunicación, a través de la selección y el tratamiento de lo informado, transmitir la ideología que los sustenta.

A continuación realizaremos una breve descripción de la metodología empleada para luego ofrecer un panorama de las características de los dos periódicos que fungirán como materiales de 
análisis: los diarios El Liberal y La Gaceta del Norte, en el marco de la prensa vasca. Los siguientes apartados se detendrán en el conflicto cristero y cómo fue expuesto en ambas publicaciones. Las conclusiones a las que hemos llegado, después de analizar la muestra escogida de 1926, cerrarán el presente texto.

\section{Metodología}

Las conclusiones que forjaremos sobre los datos obtenidos se han estructurado después de aplicar dos tipos de análisis cualitativo. Por una parte, hemos aprovechado algunos de los planteamientos relativos al análisis de contenido; por otro lado, han sido útiles también procedimientos de orden lingüístico que cristalizan en el análisis del discurso.

El análisis de contenido permite describir, en forma objetiva y sistemática, las características de un texto. En un inicio, la metodología era de índole netamente cualitativa sustentada en la manifestación textual. Las técnicas cuantitativas desarrolladas a la par, apoyaban la validez y la confiabiblidad de los resultados. Sin embargo, si seguimos las propuestas de Krippendorff (1990), hay otro aspecto de gran relevancia: el referido a los aspectos subyacentes. Las inferencias, entonces, son la puerta de acceso a la información contextual que, de otra manera, difícilmente se recuperaría.

Basado en las propuestas de Krippendorff, Eduardo López-Aranguren (1992: 391-398) describe los elementos componentes del análisis de contenido. Estos son los datos, el muestreo, las unidades de análisis, el registro, las inferencias y el análisis. Por su parte, Iñaki Zabaleta (1994: 237-298) presenta, de manera orientativa, la formulación de algunos pasos imprescindibles para desarrollar esta metodología. Estos son:

- Formular las cuestiones de investigación.

- Definir el universo.

- Seleccionar la muestra, según el universo identificado.

- Elegir la unidad de análisis y describir las definiciones operacionales.

- Formular las categorías de contenido, susceptibles de análisis.

- Determinar el sistema de cuantificación. 
- Realizar pruebas piloto que comprueben la confiabilidad de la investigación.

- Codificar los contenidos.

- Analizar los datos.

- Extraer conclusiones.

A fin de cumplir el objetivo propuesto en las primeras líneas de este trabajo, hemos planteado las siguientes preguntas de investigación:

a) ¿Qué importancia le concedió la prensa vasca al conflicto?

b) ¿De qué manera la ideología de cada medio influyó en la presentación de la información sobre la guerra cristera?

Para ello hemos escogido dos medios impresos que representan dos tendencias ideológicas distintas: El Liberal y La Gaceta del Norte.

Dada la amplitud temporal del conflicto, nos hemos centrado en las primeras dos semanas en que estallaron los enfrentamientos entre ambos bandos. Dichos 14 días generaron la información suficiente para poder comprobar la importancia concedida por la prensa vasca a los hechos suscitados en México. Así, revisamos 14 ejemplares de cada periódico durante el lapso comprendido del 25 de julio al 8 de agosto de 1926, y fijamos cada nota periodística relativa al tema como nuestra unidad de análisis. Toda nota que apareció relacionada con dicho problema fue consignada y analizada, a través de las siguientes categorías:

a) Página en la que aparece la información.

b) Tamaño concedido a la información (de acuerdo con el número de párrafos, hemos acordado una puntuación que va del 1 -toda la página- hasta el .05 (cuando la brevedad de la nota propicia su aparición en uno o dos pequeños párrafos).

c) Tipo de mensaje (informativo u opinativo).

d) Sección en la que aparece (en el caso de que se especificara alguna).

e) Mención en cabecera o sumarios.

f) Título.

g) Subtítulo. 
h) Texto (se analiza todo el texto, buscando aquellos elementos que contribuyan a responder las preguntas planteadas).

Respecto del análisis del discurso, proponemos el lenguaje como la plataforma que permite vincular al sujeto con la vida pública. La realidad sólo puede construirse mediante las expresiones del lenguaje, y en concreto, los discursos. Gracias al lenguaje podemos reconfigurar, transmitir o cuestionar las versiones concretas de un momento dado. Para lograr el objetivo fijado en este trabajo, específicamente nos centramos en lo que Jensen (1997: 211) llama "crítica textual" y ésta, es definida como "la variedad de las formas de análisis histórico, literario y lingüístico que se aplica a las grabaciones, documentos fuente, representaciones visuales y textos en el sentido más amplio".

Tres son los niveles analizados: el gramático, el semántico y el pragmático. De alguna manera incluimos el cuarto aspecto: el fonético. Y matizamos esta característica, puesto que no es nuestro fin tratar con noticiarios radiofónicos, por ejemplo. Sin embargo, mediante el análisis del uso de las grafias (uso de /j/y no /x/, por ejemplo, cuando se escribe la palabra "México") involucramos de alguna manera el factor fonético.

Ambos análisis, de contenido y del discurso, han resultado útiles para desfamiliarizar la realidad, entendida ésta como los hechos que se consideran que sí acaecieron. De antemano, damos inicio a nuestro análisis con la visión de sospecha, de duda, en cuanto a lo que se expone y se da por cierto en las muestras seleccionadas. Al desnaturalizar las temáticas y las formas y, cómo éstas son abordadas, intentamos poner las condicionespropicias para que aflore la ideología que subyace a todo texto.

\section{La prensa en Vizcaya}

El Liberal y La Gaceta del Norte fueron dos medios impresos que se publicaban en una de las provincias del País Vasco, Vizcaya, y representaban dos tendencias ideológicas distintas. En 1926 eran dos de los tres periódicos más importantes de Vizcaya (junto con Euzkadi), pero esto apenas si da cuenta del número de publicaciones con que se contaba en esa época y, sobre todo, el gran espectro ideológico que cubrían. Así, había diarios de corte nacionalista de centro derecha como el citado Euzkadi (que durante muchos años fue el de mayor venta), La Tarde, el deportivo Excélsior (estos tres estaban ligados a la 
misma empresa identificada con el Partido Nacionalista Vasco), el órgano de la Solidaridad de los Obreros Vascos (El Obrero Vasco), El Pueblo Vasco de corte monárquico como también lo era El Nervión, El Noticiero Bilbaíno (que se subtitulaba "Periódico imparcial", aunque mostraba cierta tendencia de derecha y nacionalista), además de $L a$ Gaceta del Norte, católico, y El Liberal, socialista.

Detengámonos entonces en algunos datos acerca de estos periódicos, con el objeto de tener un panorama acerca de sus rasgos más relevantes.

La Gaceta del Norte, en 1926, tenía como subtítulos: "Diario católico, Diario de la mañana". Con ellos daba cuenta ya de su filiación religiosa, así como su condición de ser una publicación de la que podía disponerse, de manera cotidiana y matutina ( Lerchundi, 1985). El apellido ideológico de este impreso, según Ofa Bezunartea (1990: 156), era el siguiente: "católico, confesional, conservador. Su línea ideológica se contemplaba enteramente desde el prisma religioso. Así había promovido la unión de derechas y nacionalistas [la autora habla desde la perspectiva de 1936], ya que estos [sic] hacían profesión de su carácter católico". Su principal impulsor fue José María de Urquijo.

Se editaba en Bilbao, en la céntrica calle de Henao, en el número 8. Durante el lapso analizado, contaba tanto con un apartado postal como con teléfono (el número 189). Fue fundado el 11 de octubre de 1901, después de haber sido gestado durante la Semana Santa de ese año, "en el transcurso de unos ejercicios espirituales celebrados en la casa solar de Loyola, propiedad de la orden religiosa. Allí el padre José María Palacio tropieza con un grupo de siete bilbaínos inquietos por encontrar un medio de lucha contra la ola de anticlericalismo imperante en aquella época" (Lerchundi, 1986: 603). Como parte de esa ola estaba el surgimiento de El Liberal, con el cual se enfrentaría abiertamente en la segunda década del siglo.

Así, en 1926 ya llevaba un largo camino recorrido, dentro de la tradición de los medios impresos de Vizcaya. Era un periódico político de opinión e información, dado el tipo de textos que publicaba. El idioma en que aparecían sus notas y su publicidad era el castellano (Ruiz de Gauna, 1990: 363). Era uno de los tres periódicos vizcaínos con mayor tiraje: aproximadamente 12 mil ejemplares diarios (Sánchez, 1992: 278). 
El Liberal asentaba como subtítulo un escueto: "Bilbao". Esto, tal vez, para que no se confundiera con otra publicación del mismo nombre como la que se difundía en el Estado español (desde 1879) que era de centro izquierda, o con cualquiera de los tres diarios del mismo nombre que vieron la luz, en 1901 en Barcelona y Sevilla (Sánchez, 1992: 234), y un año más tarde en Murcia. Unos meses más antiguo que La Gaceta del Norte, dado que salió por primera vez el 6 de julio de ese año, subsistió hasta el 18 de julio de 1937 (Almuiña, 1990: 73). Así, todavía había reminiscencias de los festejos de su vigésimo quinto aniversario, cuando comenzó a publicar la información sobre los enfrentamientos entre el Estado y los católicos en México.

$\mathrm{Su}$ fundador fue Miguel Moya Ojanguren y sus propietarios: la Sociedad Editorial de España, Horacio Echevarrieta e Indalecio Prieto (Almuiña, 1990: 72), y tanto la redacción como las oficinas y los talleres se localizaban en la calle Orueta, número 2, en Bilbao. También contaba con un apartado postal y teléfono.

Según asientan Sánchez y Barrera (1992: 235), a El Liberal le resultaba difícil defenderse "ante los ataques de los numerosos periódicos católicos: desde su fundación tuvo que enfrentarse con 'boicots' continuos". Sin embargo, los lectores respondieron bien, ya que si inició con 6 mil ejemplares diarios, siete años después ya había triplicado el número de periódicos vendidos. En la época en que nos interesa analizar este diario, su público ya estaba conformado por gente tanto de la clase económicamente acomodada como por la de menos recursos económicos.

Por el tipo de textos que conformaban a El Liberal, en 1926, podemos afirmar que se trataba de un periódico político de información y opinión. Hasta 1916 fue monárquico y demócrata; después fue republicano y a partir de 1931 fue republicano-socialista. Se anunciaba como el más vendido en el norte de España, aunque los datos de los tirajes demuestran que no era así, ya que mientras este periódico editaba 30 mil ejemplares diarios, Euzkadi publicaba 37 mil. Al igual que La Gaceta del Norte, El Liberal se editaba en castellano.

Según Enrique Herrera (citado en: Almuiña,1990: 80), El Liberal "tenía la presentación más seria" de la prensa bilbaina. No empleaba sumarios, pero sí secciones. Tenía un total de seis páginas, de acuerdo con el siguiente orden (que, sin embargo, podía variar ligeramente de edición a edición): primera plana destinada a noticias de interés 
general; segunda plana dedicada a textos periodísticos sobre el País Vasco y el Estado español; la tercera era para deportes; la siguiente, para anuncios clasificados y publicidad en general (participaciones sociales, esquelas, etc.); la quinta para más notas sobre el Estado español y la sección "Extranjero", y la última página para más publicidad.

\section{Antecedentes sobre la guerra cristera}

A principios de 1926, el presidente mexicano Plutarco Elías Calles promulgó una serie de leyes encaminadas a restringir el poder que la iglesia católica mexicana había acumulado a lo largo de casi cuatro siglos y, sobre todo, a que se cumpliera el artículo 130 de la Constitución de los Estados Unidos Mexicanos. En éste se disponía que los bienes eclesiásticos pertenecían al Estado, los sacerdotes no podían criticar las leyes y el gobierno, y los clérigos tenían que ser mexicanos de nacimiento, si querían dirigir el culto público. Entre las disposiciones que había hecho públicas se encontraba la prohibición de efectuar cualquier tipo de manifestación de culto fuera de los recintos autorizados para ello (se reiteraba el laicismo en todas las escuelas del país, al suprimir la enseñanza católica en las instituciones educativas), así como medidas tendientes a subordinar a la Iglesia al Estado (pago de impuestos, declaración de bienes, servicio militar obligatorio para los seminaristas, registro de los sacerdotes y disminución de su número, etc.) y restringir la injerencia de la Iglesia en los asuntos del Estado (se prohibía que las asociaciones religiosas obraran como grupos políticos, que sacerdotes extranjeros oficiaran en iglesias mexicanas).

Desde un inicio, las disposiciones fueron consideradas como persecutorias y atentatorias contra la jerarquía eclesiástica, por lo que sus máximas autoridades se opusieron a su aplicación y alentaron a sus feligreses a oponerse a ellas. Fracasados los intentos de que el general Calles volviera sobre sus pasos, a mediados de 1926 comenzaron a registrarse los brotes que a fines del mismo año sería declarada como la "guerra cristera". Su denominación se debe a que "los sublevados llevaban crucifijos en su uniforme y su grito de guerra era el de '¡Viva Cristo Rey!" " (A.A.V.V., 1970: 242).

Casi cuatro años duraron los cruentos enfrentamientos entre los seguidores católicos y el ejército; aun cuando la Iglesia no explicitó su 
apoyo, sí dejaba entrever que era lícito recurrir a las armas para defender la causa divina. El movimiento no fue generalizado en todo el territorio mexicano, pero sí en su región central y occidental (estados de Colima, Jalisco, Zacatecas, Tabasco y Michoacán, principalmente) (Dorselaer y Gregory, 1962: 135).

Mediante un convenio llamado Modus vivendi, firmado por el arzobispo de Morelia (capital de Michoacán) y el sucesor de Calles en la presidencia del país, Emilio Portes Gil, se dio por concluido el alzamiento. Sin embargo, todavía subsistieron diversos enfrentamientos hasta tres años después.

\section{Los inicios del levantamiento, desde la perspectiva de la prensa vasca}

El 25 de julio de 1926, en La Gaceta del Norte, en la sección "Última Hora" (a la que se le destinaba la página tres del periódico), apareció en tercer lugar en importancia en el sumario de este apartado, bajo el título "El Arzobispo de Méjico víctima del más incivil de los sectarismos", una nota de dos párrafos breves encabezada de la siguiente manera: "La persecución religiosa en Méjico".

La nota fue enviada un día antes, a altas horas de la noche, desde París, dando cuenta de la orden de detención girada en contra del arzobispo de México y de la sorpresa que suscitó esto dentro de la comunidad católica. La nota abunda en adjetivos ("La noticia de la detención del virtuoso prelado, queridísimo de todos sus dioces sanos") y la selección de los verbos y los sustantivos empleados da cuenta de quién cree el reportero tiene la razón y quién no:

El gobierno ha acentuado su laicismo y medidas de persecución, con la protesta general de la nación (...) ha ordenado la detención del arzobispo de Méjico, bajo pretexto de que ejerce presión cerca de los católicos (...) esta persecución agudizará más el conflicto entre el gobierno y la nación que repudia los procedimientos sectarios de este gabinete.

La situación de conflicto se evidencia mediante dichos recursos gramaticales, por una parte; por la otra, sobresale el empleo de la generalización ("protesta general", "la nación que repudia", "queridísimo de todos sus diocesanos") para referirse a las reacciones sobre los acontecimientos.

Ese día, El Liberal (L) no publicó nada sobre el problema, pero sí un día después, el 27 de julio, aunque no habló acerca de la orden de 
detención al arzobispo a la que se refería La Gaceta... un día antes. En esa fecha, por su parte, La Gaceta del Norte (GN) no mencionó dato alguno sobre el conflicto. Desde México, L informa sobre la decisión de los obispos mexicanos de oficiar la misa del domingo 31 de ese mes, en protesta contra las nuevas leyes. La nota es sumamente escueta (un pequeño párrafo), sin comentario alguno por parte del redactor, apareció en la sección destinada a la información proveniente del extranjero, en la quinta página, donde usualmente se insertaban ese tipo de noticias.

La misma nota de L será publicada al día siguiente por GN. La exactitud de los términos empleados en ambas hace parecer que fue tomada del despacho de alguna agencia informativa, aunque en ninguno de los casos se menciona la fuente. La diferencia estriba en que si L la destina a su página cinco, GN la inserta en la primera plana, en su parte inferior, sin destacarla demasiado al no asignarle sumario alguno.

El 29 de julio, GN publica tres notas relativas a este problema, mientras que L, una. La primera de ellas aparece en la página uno (con pase a la dos): es el único artículo de opinión que GN le dedicara al conflicto y también el único firmado, en los 15 días que cubre la muestra. Sobre este escrito volveremos en el apartado dedicado a este tipo de mensajes.

Ese mismo día, jueves 29 de julio de 1926, en la sección "Última Hora", la guerra cristera ganará el titular y la segunda nota en importancia con "Los católicos mejicanos se aprestan a la defensa" y "El vecindario de Nóchixtlan se amolina contra el alcalde, que maltrató a un sacerdote católico, asalta su casa y lo lyncha (sic)". Proveniente la información de París, la primera de ellas toca diversos hechos: la efervescencia que reina entre los católicos en contra del gobierno y la disposición de los creyentes a las represalias de tipo económico; el abarrotamiento de las iglesias para confirmaciones y asistencia al culto, en vista de que el próximo 1 de agosto no habría servicios; y el envío de seminaristas mexicanos a escuelas del sur de Estados Unidos.

La segunda nota es un poco más breve y se refiere al asesinato de un alcalde del estado de Zacatecas (aunque la nota es enviada desde otro estado de México: Aguascalientes), en manos de la muchedumbre, debido a que maltrató a un sacerdote. No se confirmó el hecho, pero se cree que murieron también de la misma manera personas cercanas a la 
autoridad municipal. Finaliza con una evaluación por parte del redactor: "La indignación en esta parte del país contra la persecución es muy grande y se cree han de producirse nuevos sucesos".

L también publicó este hecho en la sección dedicada a la información del extranjero, bajo el título "Alcalde linchado". La nota aparece enviada desde México y no especifica la fuente de donde provienen los hechos, ya que empieza de la siguiente manera: "Dicen de Aguas Calientes que en el pueblo de Nochistán, de la provincia de Zacatecas, la multitud invadió el domicilio del alcalde...". Así como en el caso de GN, se difunde un hecho que se llegó a saber en Aguascalientes, pero que sucedió en un pueblo de Zacatecas (actualmente, a casi tres horas por carretera). Y se añade: "Los periódicos de la capital dicen que...". Al parecer, la fuente real son los periódicos de la ciudad de México (aunque también podrían ser los de la capital del estado de Aguascalientes). L difiere con GN en el hecho de que el sacerdote que fue maltratado por el alcalde, murió, aunque se aclara que esto no ha sido confirmado.

Estas primeras notas dieron cuenta de la tónica que siguió la información en los próximos 13 días: una mayor injerencia del redactor en las publicaciones de GN, en tanto que el de L evitó la mayor parte de las veces todo tipo de comentarios; usualmente GN le concedió mayor espacio al conflicto que L, con titulares de mayor dimensión; los hechos y los comentarios de los titulares de GN tuvieron efecto más sensacionalista que los de L; mayor uso de sumarios por parte de GN, en relación con L. Otras características aparecieron luego, cuando el problema se agudizo: tendencia a publicar la información sobre la guerra cristera en la primera plana, en el caso de GN y resistencia de L a hacerlo; sin embargo, L creó una sección especial para referirse a estos hechos: "Lo de Méjico". En ambos casos se registró una inclinación por recurrir al mismo tipo de fuentes ( $\mathrm{GN}$ a las provenientes de la Iglesia católica -mexicanas, del Vaticano, de otros países- L, a las gubernamentales, los sindicatos).

\section{La segunda semana del conflicto}

El sábado 30 de julio, GN incluyó, dentro de sus notas principales del día, una dedicada a la guerra cristera. Sería la primera de una serie de informaciones que se desplegaron a lo largo de toda la siguiente semana, en la portada del periódico. Conforme avanzaron los días, lo que se publicó sobre México fue ganando cada vez más espacio en este 
diario. Cinco días en portada, con un espacio que oscilaba entre 40 y $75 \%$ del total de la plana, además de una mayor información al respecto en interiores (con cuatro notas distintas, incluso, el 7 de agosto, por ejemplo) dio una idea de la importancia que el periódico le concedía a este conflicto mexicano.

L mostró una tendencia distinta. Dedicó su portada, en un lugar más discreto y con menos espacio que el que GN le brindó al problema, sólo en dos ocasiones: una el 1 de agosto y la siguiente vez, seis días después. El resto de la información sería asignada a las páginas interiores y el espacio que ocupó no fue muy amplio, en relación con GN: únicamente el 4 de agosto se le dio $20 \%$ del total de la quinta página. Las otras 16 notas que aparecen en torno de esta guerra, durante las primeras dos semanas, oscilaron entre 5 y $15 \%$ del total de la página.

Destaca el hecho que el día en que ambos periódicos le concedieron más amplitud de espacio al tema fue el mismo. GN dedicó, entre todas las notas publicadas el 7 de agosto, casi la totalidad de una página: $95 \%$, entre lo que aparece en portada y la sección "Última Hora". Esa misma fecha, L dio $25 \%$ de su espacio, entre una nota en portada y una en la página dos. La coincidencia se desvanecerá, cuando analicemos el tipo de información que ambos medios publicaron, tal y como veremos a continuación.

Las peregrinaciones al santuario de la virgen de Guadalupe, la situación en estados como Tlaxcala y Querétaro, las acciones que están dispuestas a emprender las asociaciones religiosas y los empresarios, la exhortación del Congreso del Trabajo a apoyar al presidente Calles, y la formación de una "Liga" encargada de defender los cultos son los temas que se abordan en la nota de la primera página de GN del 30 de julio. En prácticamente una columna natural, la cuarta, de la página principal se desarrollan dichos temas.

La nota abre con un titulary dos subtítulos: "Cinco mil personas han ido descalzas a la capilla de Guadalupe" y "Es preciso colocar altares al aire libre". Luego la divide en dos textos diferentes: uno dedicado a los católicos y otro a los anticlericales. El primero de ellos es titulado "Latigazos a las mujeres para disolver una manifestación" y por su extensión, sensiblemente más larga que la destinada al segundo texto, exhibe un ladillo que reza "Al lado de los prelados". 
Esta primera parte de la información emplea un gran número de adjetivos que califican lo acaecido ("vandálicos hechos", "violentos encuentros") de manera conflictiva y agresiva, pero siempre refiriéndose a la parte gubernamental ("soldadesca", "fuerza pública"). Se emplean sustantivos que indican violencia, con un cariz de calificación, comenzando con el titular ("Los católicos mejicanos ante la persecución"), pero también con frases como: "la hostilidad con que son tratados los católicos mejicanos". Y también verbos que comunican una idea similar a la de los otros elementos gramaticales ya citados: se "dicta", se "prohibe", se trata de "impedir", se "toman militarmente las calles", "provocan general indignación".

Cuando se trata de los seguidores católicos, los adjetivos varían y su grado también: "las más fervorosas peregrinaciones que recuerda la historia de aquel país" se encaminan hacia la Villa de Guadalupe. Según el planteamiento del diario, la actitud de los fieles es netamente defensiva y de total acuerdo con la jerarquía eclesiástica. Los sustantivos que más abundan tienen que ver con un campo semántico claramente ideologizado: "principios", "ideales", "creencias religiosas", "tenacidad", "incondicionalidad".

Si la primera información consta de 11 párrafos, la relativa a la Confederación de Trabajadores en México posee tres. De éstos, sólo uno es relativo a dicha Confederación, ya que el primero da a conocer las consecuencias del boicot económico protagonizado por los católicos (Beyhaut, 1965: 193) y el último, la organización de la Liga que defenderá la libertad de cultos. Es decir, el párrafo relativo a la disposición de los trabajadores para apoyar las medidas presidenciales, queda entrampado por dos datos que cuestionan la viabilidad de esa decisión. Por otra parte, el título de la nota es engañoso, ya que al encabezarse con "Actitud de los socialistas", se está relacionando a una Confederación Obrera con una ideología inexistente en esa organización. La Confederación Obrera Mexicana era progubernamental, pero de ninguna manera socialista. El partido político en el poder era el Revolucionario, cuyos orígenes y posterior desarrollo estaban muy distantes de la doctrina socialista.

Por su parte, L únicamente da cuenta de la actitud de la Confederación del Trabajo, la cual invita a combatir el boicot de los católicos, y del inicio de la organización de una "Liga" que defendería la libertad de cultos. La nota se titula "Clericales y anticlericales en 
México", se desarrolla en dos breves párrafos de la página cinco. Es de destacar que ya no se incluye dentro de la sección "Extranjero", sino que se inserta como una nota suelta.

L omite, voluntariamente o no, tanto los hechos violentos acaecidos, como la declaración de representantes de las asociaciones católicas o eclesiásticas, y las consecuencias del boicot de los católicos a la economía nacional.

En ambos casos, las noticias provienen de París: L lo explicita en el interior de su nota, mientras que GN inicia su información con el lugar de donde les es enviado el texto. No obstante, GN inicia el escrito diciendo: "Según noticias recibidas de México...", aunque al finalizar se señala "añaden las noticias de México recibidas en París". Una de sus fuentes es el Journal des Debats, otra es la presidenta general de la Asociación de Damas Católicas, la tercera es el vicepresidente de la Liga Nacional de Defensa Religiosa, una más son "periódicos mexicanos llegados a España en el último correo". Todas estas fuentes aparecen en la información sobre los católicos; en la que se refiere a los anticlericales, no se menciona ningún nombre que se responsabilice de la información, sino la institución que la emite: la Confederación del Trabajo.

Los tres días siguientes, GN no publicó ninguna información sobre la guerra cristera. L, en cambio, sí. El 31 de julio de 1926, llevando de titular "En pro y en contra del poder civil", en la misma página cinco, pero en la sección "Al cerrar la edición", L da a conocer muy brevemente (en un párrafo) algunas acciones llevadas a cabo por el gobierno mexicano. Éstas iban encaminadas a desalentar la formación de nuevos grupos opositores: el desarme de "todos los católicos en territorio mexicano", y la supresión de sus reuniones nocturnas. No se especifica informante alguno, y la información se funda en un "se ha sabido". El origen de la nota proviene de México.

Al día siguiente, 1 de agosto, El Liberal publicó en portada y en interiores datos sobre el enfrentamiento cristero, en un texto enviado desde París. Fue la primera de las dos únicas veces en que se insertó en la primera plana una noticia al respecto. En ella, se tocan diversos temas: según una información emanada de Washington, el Ku-klus-kán [sic] "se opone a la intervención de los Estados Unidos" en el conflicto; los diputados socialistas mexicanos se declaran en favor de la política presidencial y llevarán a cabo una gran 
manifestación el día que entrarán en vigor las nuevas leyes referentes a la separación efectiva entre la Iglesia y el Estado; el alto clero mexicano estima que los bienes que le incautarán ascienden a más de 300 millones de dólares; por último, se informa que así como el papa ha tenido éxito en sus gestiones diplomáticas con Polonia y Argentina, confía tenerlo en México.

Con una extensión similar, con el subtítulo "Última Hora", L cabecea: "En México han ocurrido luchas sangrientas"; esta cabeza es compartida por tres textos despachados desde tres lugares distintos: Londres, México y Roma. Mujeres heridas y detenidas, agresiones a funcionarios gubernamentales y el avizoramiento de disturbios ante la inminencia de la puesta en vigor de la ley mencionada, son los asuntos que aborda la nota enviada desde la capital inglesa. A continuación se inserta un párrafo proveniente de México, en el que se habla sobre una reyerta en Puebla, con saldo de un muerto y dos heridos. Y, por último, de manera muy breve desde Roma se da a conocer la detención del secretario de la delegación apostólica en México, quien fue conducido a la frontera.

En el primer caso se alude a la impotencia de la policía ante la negativa de las personas reunidas, a abandonar la iglesia en la que se encontraban. Por ello, "tuvieron que hacer fuego contra los fieles". En lo que a las mujeres detenidas se refiere, el hecho se debió a que realizaban "propaganda contra el Gobierno". La imagen que es proyectada por el medio, a través de este texto, es la de desobediencia de los católicos hacia el orden público, debida a sus creencias (en todos los casos se alude a la pertenencia a asociaciones o grupos religiosos).

El enfrentamiento entre vecinos y cómo la guerra cristera afectó el ámbito cotidiano de los estados de la provincia mexicana, principalmente, se transparenta en la segunda parte del texto. Sin embargo, si dentro de la población en general repercutió el conflicto de manera sangrienta, la tercera parte del texto alude cómo la alta jerarquía eclesiástica podía ponerse a salvo.

El 3 de agosto, L crea una sección a la que denomina "Lo de Méjico". Con ello alude a la información vertida desde una semana antes y el supuesto conocimiento de los lectores acerca de la naturaleza del problema. Esta misma semana, el 5 y el 8 de agosto, volverá a aparecer esta sección. Resalta que los demás días, de manera ininterrumpida siguió publicándose acerca de la guerra cristera, pero 
sin especificar la sección, sino como notas sueltas, en la quinta página (donde suele aparecer, a un lado de la sección destinada a las notas que se refieren a hechos acaecidos en el extranjero), en la dos o en la tres, principalmente.

La primera nota de "Lo de Méjico" se titula "Un complot contra el presidente Calles". Se refiere al arresto de varias personas implicadas en un plan para atentar contra el presidente mexicano; entre ellas, varias mujeres. También se habla del patrullaje nocturno, el registro de los transeúntes y la confiscación de armas.

La segunda nota, "Protesta de Inglaterra por la confiscación de un templo protestante", abunda sobre la incautación de un bien propiedad de ciudadanos británicos, que fungía como una iglesia episcopal y la respuesta del gobierno mexicano "que estudiará con toda atención el asunto".

El tercer texto, "El episcopado propone un plebiscito", trata de la propuesta de la iglesia católica de pactar una tregua con el gobierno mexicano, con el objetivo de convocar a un plebiscito entre la ciudadanía sobre las leyes religiosas. También se menciona que hubo una manifestación de socialistas en adhesión al gobierno.

La última información, "Más muertos y heridos", describe un enfrentamiento entre un grupo que rodeaba una iglesia y policías. El resultado fue de varios muertos y nueve heridos. En Pacheco, seis mujeres y seis niños murieron asfixiados por la aglomeración que había en una iglesia.

La tónica es semejante a la de las notas de días anteriores, ya que se subraya el papel agresor de los católicos y el defensivo de la policía y las tropas: "al tratar la policía de dispersar un grupo que estaba rodeando una iglesia, una mujer lanzó una piedra contra un policía, y le mató". Como respuesta, los agentes mataron a la mujer, lo cual originó "grandes disturbios".

Por otra parte, de la confiscación de los bienes de un templo protestante se deduce que las leyes puestas en vigor no son anticatólicas específicamente y que ésta no es una medida dirigida a un culto determinado. Además, vuelve a llamar la atención la referencia a un hecho no comprobado: "Dicen de Pacheco (...)".

Como puede comprobarse en los titulares empleados en este día, $\mathrm{L}$ evita el empleo de calificativos y centra su interés en la descripción de 
los hechos más relevantes de la jornada. Así, aun cuando hay información sobre una manifestación de socialistas, ésta no se destaca ni en los títulos, ni en el espacio que se le concede (un pequeño párrafo de cuatro líneas). En las notas insertas en "Lo de Méjico" se cubre un amplio espectro de los ámbitos relativos al tema: el gobierno mexicano (denuncia de un complot en contra del presidente), las relaciones exteriores (protesta del ministro plenipotenciario de Inglaterra), el episcopado católico mexicano, otros grupos políticos (los socialistas) distintos al del gobierno y las repercusiones del problema en la población y las fuerzas públicas.

Por su parte, el 3 de agosto dedica La Gaceta del Norte más de una cuarta parte de su primera plana a la guerra cristera y tres notas muy breves en la tercera página, dentro de la sección "Última Hora". Los textos de la portada cuentan con un titular que los aglutina "Todo el mundo civilizado se alzará contra la barbarie persecutoria mejicana", que se caracteriza por su cariz opinativo y la generalización del sujeto de la oración. El subtítulo es "La bárbara persecución de los católicos por el sectarismo mejicano" y prosigue con las mismas características del titular. La repetición de las ideas de persecución y barbarie en dos oraciones tan cercanas indica el énfasis con que se desean proyectar al lector (a lo largo de las informaciones dicha intención se seguirá destacando e incluso, habrá una nota de la redacción que exclamará "¿Qué bárbaros!”).

Los sumarios son los siguientes: " $Y$ Y luego hablan estos grandes farsantes de la libertad de la prensa!”, "Más de 100000 confirmaciones en la capital","Veinte católicos villanamente asesinados en las iglesias por la soldadesca", "Gravísima situación del Banco de Méjico y de los Montes de Piedad", y "El senador Sr. Galván y un juez muertos a tiros por un diputado".

Es de destacar cómo se polariza a los protagonistas del suceso (designémosles como a y b), a partir de la información vertida entre el titular, los subtítulos y el sumario:

a) Perseguidores $=$ bárbaros $=$ sectarios $=$ grandes farsantes $=$ villanos $=$ representantes del gobierno mexicano (soldadesca, policías).

b) Perseguidos $=$ creyentes católicos.

Mientras que sobre los protagonistas del núcleo a se vierten adjetivos y es posible forjar una caracterización que se relaciona con la 
irracionalidad, los protagonistas del núcleo b son replegados a un papel pasivo, receptor y carente de adjetivaciones adversas. Esto, entonces, contrasta con la propuesta de El Liberal, en donde son los católicos, precisamente, quienes desempeñan el papel activo, agresor.

Dentro de los 17 breves que conforman este texto de portada, tres no son generados en México (sino en Santiago de Chile, Washington y Roma); pero ninguno es enviado desde el país escenario del conflicto, sino desde París (excepto en el caso de Roma y Chile).

Dentro de la información de este día, martes, GN publica notas que ya habían sido dadas a conocer con 24 horas de anterioridad por L, como son el complot en contra del presidente mexicano, la confiscación de bienes de los religiosos ingleses, la propuesta de una tregua por parte del episcopado católico, y los enfrentamientos entre policías y creyentes. Es decir, básicamente se cubre toda la información difundida por $\mathrm{L}$, con excepción de la marcha de adhesión de los socialistas. El enfoque, sin embargo, es totalmente distinto. Veamos:

- Al referirse GN a los planes para asesinar a Calles, la nota es titulada “UUn complot?” La interrogación con que se inserta en GN contrasta con la afirmación del titular de L. Aunque los datos, fundamentalmente, son los mismos que los asentados en L, en GN la señora que se busca, como presunta dirigente del complot, es "respetable" y "de muy distinguida familia".

- Sobre el caso de los bienes ingleses incautados, hay una gran diferencia entre el acento que plantean ambos medios de comunicación. Así, si L dice "La nota, aunque amistosa, está redactada en términos enérgicos", por la información expresada en GN pondríamos en duda lo "amistoso" de la carta enviada al gobierno mexicano, dado que está "Inglaterra contra la confiscación de bienes", está dispuesta "a ponerse al lado del Vaticano para protestar" y "adoptará las disposiciones que considere oportunas".

- El saldo de muertos y heridos es abordado por ambos periódicos, ya que los dos informan tanto sobre el enfrentamiento entre las tropas y la población católica como de los resultados de la aglomeración en una iglesia. Sobre este último dato, la formulación escrita es muy semejante, lo cual permite inferir que se trata del despacho de alguna agencia informativa no especificada o de la extracción de alguna nota local mexicana publicada en términos parecidos. En donde hay 
variaciones de expresión y contenido, a pesar de que la esencia de los hechos (número de muertos, lugar del acontecimiento) es la misma en la información primera.

Como asentamos anteriormente, $\mathrm{L}$ proyecta la inevitabilidad de la actitud de la policía, la cual sólo se defiende de los ataques de una mujer; esto da pie a un zafarrancho, en el que -entre otros- mueren el policía apedreado por la mujer y ésta, en manos de los compañeros del agente del orden. El titular que encabeza ambas notas es un indicativo del punto de vista que subyace a ambas publicaciones: "Aumentan las víctimas" dice GN; "Más muertos y heridos" sentencia L. Así, aunque la esencia informativa es la misma, GN es consecuente con la opinión que profesa sobre quiénes son los perseguidores y quiénes los perseguidos, quiénes los agresores y quiénes las víctimas (sobre todo porque en el texto no se menciona que el disturbio dio inicio debido a la muerte de un policía, provocada por la agresión de una mujer católica). $\mathrm{L}$, en esta nota, es menos explícito acerca de qué piensa sobre el conflicto.

GN no informa sobre el papel activo de la mujer e invierte los hechos: "Las tropas continúan atacando a los católicos que se hallan en los alrededores de las iglesias, pero procurando hacer objeto de sus disparos a las mujeres". L habla de intentos de "dispersión", GN de "ataques"; este medio transmite la idea del deseo de dañar a las mujeres, en tanto que L no menciona nada de esto y sí que "una mujer lanzó una piedra contra un policía y le mató".

En cuanto a los demás textos que versan sobre este conflicto, GN exhibe, en ese día, una cobertura mayor en el número de notas y con un énfasis totalmente diferente al de L. Los datos de los que éste no da cuenta son los que GN titula de la siguiente manera: "La libertad de prensa", "Cien mil confirmados", "La incautación de las iglesias", "Veinte muertos", "Los mejicanos huyen", "En pleno atropello", "Muertos a tiros", "La catedral de Méjico rodeada por la policía", "Las naciones sudamericanas protestan", "El boicot de los católicos", "Las legaciones preocupadas", "El presidente Coolidge" y "Ceremonias expiatorias".

Ya hemos mencionado la inserción de una de las notas de la redacción que se incluyen bajo el gran titular desplegado en la portada del 3 de agosto de GN. Otra de las notas de la redacción aparece subyaciendo al primer texto "Libertad de prensa" y se refiere a la 
prohibición a los periódicos de hablar mal del gobierno y el procesamiento de los directores de dos periódicos (no se menciona cuáles) por haberlo hecho. La N. de la R. reza así: “¡Pero qué liberales son estos anticlericales!" En ella es obvio el acento irónico.

Nos parece importante la estrategia de colocar este texto en primer lugar, a pesar de que periodísticamente podría ser cuestionable el orden en que ha aparecido, dado que se contaba con información de peso como la muerte de un senador, un juez y un transeúnte y un diputado gravemente herido, a consecuencia de un altercado suscitado por la discrepancia de opiniones sobre las leyes de Calles. O bien, dada la ideología del periódico, la confirmación de más de 100 mil personas. Sin embargo, la eficacia de ese primer texto gira en torno de dejar claro en el ánimo del lector la ambigüedad del gobierno mexicano que se declara liberal, pero que obra en forma inversa. De esta manera, se añade un elemento de juicio que favorece a los católicos, en su demanda de derogar una ley que proviene de un gobierno mentiroso (bárbaro, sectario y farsante, entre otros adjetivos que, como hemos explicado, aparecen en la cabeza de la nota).

La polarización de opiniones en cuanto a los protagonistas de los hechos, gobierno e Iglesia, es visible en cada uno de los textos publicados ese día. Así, en "Cien mil confirmados" se destaca la pérdida del conocimiento del arzobispo mexicano debida al "cansancio y la emoción", es decir, ha puesto en riesgo su salud para cumplir con su deber.

En "La incautación de las iglesias", se dice que "un número elevadísimo de señoras de la mejor sociedad han enviado un mensaje (...)" En cambio, en este mismo texto, se informa que "El Gobierno ha dado orden a los alcaldes para que se adueñen de todas las iglesias". Redactado de esta forma, el lector bien puede creer que los presidentes municipales se apropiarían de los bienes eclesiásticos para su beneficio personal, cuando el espíritu de las leyes dictadas era que pasaran a ser dichas riquezas parte del patrimonio nacional. Así, mientras los católicos envían mensajes para que se "endulcen" las citadas leyes, el gobierno arrebata injustamente lo que no es suyo. En ese mismo texto se afirma que "buena parte" de dichos alcaldes son "francmasones".

En "Veinte muertos", los católicos son "víctimas de la barbarie de los perseguidores de la Iglesia" y se oponen a ello "valiente- mente". 
Por su parte, las tropas acuden para "imponerse" a los fieles haciendo fuego.

"Los mejicanos huyen" dedica la mitad de su breve información al tema del encabezado y la otra a otros tópicos distintos (los problemas de solvencia que atraviesan el Monte de Piedad y el Banco de México). El estado de crisis que ha provocado el gobierno mexicano, se infiere de la lectura de esta nota, ha propiciado que los ciudadanos salgan de la ciudad de México y se dirijan a la provincia del país o al extranjero, pero también que se encierren en sus casas varios días, después de abastecerse.

La N. de la R. que exclama “iQué bárbaros!” pertenece a la nota "En pleno atropello", en la que se dice que el gobierno mexicano ha autorizado la sustitución de los sacerdotes para que "determinados individuos" casen y bauticen. Históricamente, esta información es falsa, dado que los jueces de paz fueron instruidos para legalizar los matrimonios civiles (no los religiosos) y nunca los bautizos. Sin embargo, es cierto que en Tabasco, por ejemplo, el fuerte anticlericalismo del gobernador Garrido Canabal lo llevó a prohibir el ejercicio de ningún sacerdote, a menos que estuviera casado. Sin embargo, la información de GN es muy general y no llega a abordar casos específicos, proporcionando datos que pudieran ser verificados.

El titular que aglutina los textos anteriores ("Todo el mundo civilizado se alzará contra la barbarie persecutoria mexicana") se fundamenta en notas periodísticas que versan sobre la condena de otros países hacia la política interior mexicana. Sin embargo, al confrontar la contundencia del encabezado -que da por hecho que se tomarán medidas al respecto- con el contenido de la información, es posible darse cuenta que en varios casos se habla de que es probable que se adopten ciertas medidas o bien, como en el caso del gobierno británico (donde se afirma que éste "adoptará las disposiciones que considere oportunas"), la información se opone a la publicada por L. En cualquiera de los dos casos, podemos percatarnos que el titular es muy cercano a las técnicas propagandísticas que luego se emplearían por la prensa, durante la guerra civil española.

Uno de los textos que apoyan el encabezado principal es "El presidente Coolidge". La "indignación" de yankis de otras religiones y la "gran agitación" de los católicos, el que el presidente Coolidge se encuentre "muy preocupado" y la "muy probable" intervención de 
éste, si la situación se agrava más, son los ejes de esta nota. En ella, se trasluce la aprobación de la injerencia de EUA "para reprimir los atropellos del presidente Calles".

Los mítines celebrados en las provincias mexicanas (no dice cuáles), en los que se pide la cooperación de los católicos de las demás repúblicas hispanoamericanas son el motivo de "Las naciones sudamericanas protestan". Se dice que "Han respondido favorablemente Argentina, Brasil, Colombia, Ecuador y Venezuela", pero no se amplía esta información. De aquí que no se sepa en qué consiste dicha respuesta, ni tampoco queda claro si han protestado, tal y como lo anuncia el titular de la nota (Beyhaut, 1965: 263).

El alzamiento "contra la barbarie persecutoria mexicana" también parece fundamentarse en la nota "Las legaciones preocupadas"; se menciona a España, Francia e Inglaterra, aunque en el caso de las dos primeras no se asienta nada que pudiera indicar alguna acción más que la preocupación que se "nota" en sus legaciones en México (no se determina cómo es notada tal preocupación). En el caso del gobierno londinense, "se cree" que habrá una intervención, "parece que" está dispuesta a impedir la expulsión de sus sacerdotes y la incautación de los bienes de éstos. Vuele a ser contrastante, entonces, la contundencia del encabezado general con la información particular.

En Roma y Madrid hubo actos religiosos, donde se imploró porque cese la persecución de los católicos en México, según se señala en "Ceremonias expiatorias". En ambos casos, se habla de rogativas e imploraciones, para que cesen los problemas religiosos en México; en estos textos vuelve a evidenciarse la caracterización católico/pasivo/perseguido/víctima y anticlerical/activo/persecutor /verdugo, que permea en la transmisión de la información de GN.

Por otra parte, el 4 de agosto, en la quinta página de $\mathrm{L}$ y sin especificar la sección en la que se insertan, aparece una nota sobre la guerra cristera. Se encabeza así: "Los católicos frente al poder civil en Méjico". Ocupa casi una columna natural, la primera de dicha página, y está compuesta por siete textos breves. En ella se reitera la visión que desde días anteriores L había estado proyectando, en cuanto al papel agresor de los católicos (son éstos lo que se enfrentan al poder civil, según el titular de la primera nota) y el de cierta tolerancia del gobierno de Calles (a pesar del complot, destaca el titular de la segunda nota, no se viola el orden de derecho de los presuntos implicados). 
En relación con lo publicado en GN ese mismo día, L ofrece una mayor información sobre el punto de vista del gobierno mexicano, a través de notas como las siguientes: "La manifestación obrera y el complot contra Calles", "Obregón de acuerdo con Calles", "Calles no admite tregua" y otras que en su contenido también se refieren neutra o favorablemente hacia la política de Calles: "Intervención de los diplomáticos americanos", "Los protestantes lo mismo que los católicos”, “Habrá negociaciones?”, “El gobierno de Washington, neutral".

De los siete textos que componen esta nota, cuatro se basan en un "Dicen que (...)", sin que se especifiquen las fuentes; en otro caso se habla de una "fuente autorizada". Sólo dos notas provienen de México (la relativa a que Calles no ha aceptado la propuesta de la jerarquía católica de un plebiscito y la que se refiere a la aprobación del expresidente mexicano Obregón a la política de Calles), mientras que las demás se despachan desde París y Londres.

En esos textos se configura una visión de un gobierno conciliador, apoyado popularmente, y que, "firme", no admite la injerencia de otros países, con altas posibilidades de conflicto con éstos debido a la política adoptada. Así, se habla de una manifestación de 50 mil individuos (10 mil de ellos, mujeres) organizada por la Confederación General del Trabajo (Beyhaut, 1965: 260), la confiscación de los bienes eclesiásticos de todas las religiones y no únicamente la católica, la solicitud de diplomáticos de América del Sur (no se dice de qué países) de una tregua y la autorización de Calles para que un representante suyo entable conversaciones con las autoridades eclesiásticas para solucionar esa crisis. Sin embargo, esta conformación de la figura gubernamental sólo es perceptible en L a través del conjunto de los textos, el tipo de información que ofrece y la selección de los datos publicados. Es decir, no hay una explicitación de qué se piensa acerca del problema, como en el caso de GN, en donde la opinión del redactor es mezclada con el hecho en sí mismo.

El miércoles 4 de agosto, GN incrementó el espacio que le había dedicado al problema. Aun cuando, en esta ocasión, no proporciona información en interiores, en su portada le destina tres columnas naturales; es decir, la mitad de la primera plana. Formalmente, presenta algunas peculiaridades la presentación de los textos que aparecen y se repiten otros rasgos. Así, por cuestiones de diagramación y la cantidad 
de información generada, este día es posible diseñar tanto un titular a lo largo de las tres columnas ("Los católicos de Méjico se aprestan a la defensa") como dos subtítulos "En diferentes lugares del país los funcionarios del gobierno que fueron a incautarse de las iglesias han sido recibidos a pedradas y a tiros" y "El Times dice en un artículo que es una pequeña minoría la que quiere imponer su sectarismo a la inmensa mayoría de un pueblo que es esencialmente católico".

Las ocho líneas que integran el titular y el subtitular exhiben tanto cuerpos como tipos de letra distintos, a fin de destacar unas líneas, en relación con las otras. Por ejemplo, en el segundo subtítulo, al aumentar el tamaño y variar el tipo de la letra, el lector inmediatamente percibe la frase "imponer su sectarismo", por encima del resto de la información que conforma toda la oración. O bien, el mayor tamaño de la primera línea del titular y el que esté puesto en cursivas destaca "Los católicos de México". Dado el tipo de público lector al que va dirigido este diario, es evidente que la cabeza no sólo está cumpliendo con una función informativa, sino también de punto de atracción para el posible consumidor.

Otro rasgo que sobresale en lo que aparece el 4 de agosto en GN es la presencia de un recuadro, cuyos corondeles están muy adornados y su cabeza destaca, al ir toda en mayúsculas (en tanto que el titular y los subtítulos van escritos en altas y bajas). "¿Movimiento armado? Mentira lo del complot" es el título de este breve texto que aparece centrado, dentro de las tres columnas que ofrecen ese día la información sobre México. En el texto se abordan dos temas distintos, en tanto que el titular los vincula.

El primer ámbito se refiere al acopio de armas que "mexicanos de gran significación" están haciendo en Texas, a fin de derribar al gobierno de Calles. El segundo, proveniente de Londres, dice que Daily Express (periódico estadounidense) recibió, a su vez, un cable, que asegura que el complot contra Calles "fue únicamente un invento de un extranjero, que aprovechó las circunstancias para ejecutar una venganza". A pesar de lo confuso del envío (¿de qué extranjero se habla?, ¿qué tipo de venganza?, ¿contra quién iba ésta dirigida?, etc.), en los días siguientes no se dedicó espacio alguno para aclarar la nota, para ratificar si lo del complot a Calles fue mentira o no, para enmendar la afirmación del titular, si así se requiriera. 
El resto de los escritos que se incluyen en esta fecha abarcan una gran variedad de temas relativos a la rebelión cristera, provienen de distintas fuentes y son despachados desde diversos lugares. Se continúa informando sobre las distintas muestras de descontento expresadas tanto en el interior del país como en el extranjero acerca de la actitud del presidente Calles (no permitir que se oficie ni en los asilos, expulsar al delegado pontificio, requisar las armas de fuego de los ciudadanos, incautar los templos incluyendo los protestantes, evitar grandes concentraciones alrededor de las iglesias y detener a los sacerdotes). Estos tópicos son abordados en cinco pequeños textos. También hay información sobre la gravedad de quienes resultaron heridos en los disturbios de días anteriores; el que distintas legaciones diplomáticas sigan "estudiando cuidadosamen- te" ofrecerse como mediadoras para la resolución del conflicto; las reacciones que en EUA suscitó un comunicado de la embajada mexicana que hablaba sobre la postura del gobierno de este país; y la negación de distintos miembros de la Federación General de Trabajadores a participar en las muestras de adhesión al gobierno, dado que la organización debería permanecer al margen del problema.

Los escritos que informan sobre los temas anteriores son de extensión semejante. Sólo uno difiere de esta tónica de brevedad exhibida y es uno que reproduce varios fragmentos de un editorial publicado por el Times londinense. En él se aventura la razón por la cual Calles pudo haber decidido aplicar los artículos de la Constitución de 1917, cuando ni Porfirio Díaz ("el fuerte y sagaz tirano") puso en práctica lo asentado en las Leyes de Reforma dictadas a mediados del siglo pasado. El otro punto sobre el que giran los párrafos transcritos es la interrogante sobre qué organización va a sustituir la labor que venía ejerciendo la Iglesia católica, en cuanto a la difusión de ideas religiosas y morales.

Los breves titulares que encabezan toda esta información están marcados por el uso de elementos gramaticales que, en su interrelación, connotan una idea de conflictividad: "a defenderse", "los heridos", "tratando de engañar", "Calles es el culpable", "obreros disconformes", etcétera.

Los despachos provienen de Londres, Roma, Nueva York, Washington y México, y se citan tres fuentes periodísticas de donde ha 
sido extraída información: el Times de Londres, El Universal de México y el Diario de la Marina de La Habana.

A pesar de la extensión y amplitud de lo que se da a conocer sobre la guerra cristera en GN, el 4 de agosto, se sigue observando una parcialización del problema. Lo notamos tanto en la temática abordada (en donde se concede un espacio mucho mayor al ámbito eclesiástico o de apoyo a éste; cuando hay una referencia al punto de vista gubernamental es planteado en términos despectivos, incrédulos o adversos), como en los titulares. En éstos persisten los rasgos identificados en otros días: la polarización de los campos semánticos ya descrita, la función exhortativa de los encabezados (en pro de la defensa de los creyentes) o descalificativa (en cuanto al gobierno mexicano, Calles y los socialistas). Quizá la característica más sobresaliente de esta fecha es la inclusión de un artículo de opinión (que no se especifica como tal) y la glosa del editorial del Times.

La información más extensa que L dedicara, en el lapso de la muestra estudiada, fue publicada el 5 de agosto de 1926. Alrededor del $20 \%$ de la quinta página y en la sección originada a raíz del conflicto ("Lo de Méjico"), el titular "Un periódico inglés recoge la noticia de un atentado contra Calles" abarcó también otros cuatro textos (además del que alude el encabezado) sobre igual número de temas. La información provino de París y de Londres, la cual sólo retransmite lo publicado en otros medios como algunos no especificados de Nueva York y París, y el londinense Daily Telegraph.

La declaración de Alfonso Reyes, representante diplomático de México en Francia, a un diario parisino es transcrita, dado que a juicio de L las del también prestigiado escritor mexicano son "interesantes manifestaciones". Reyes se preocupa por desmentir la inminencia de una guerra civil en su país y explica la naturaleza del problema que ahí se vive. Recuerda la antigüedad de las leyes que subordinan al clero, al gobierno civil y cómo la tolerancia de Porfirio Díaz hacia aquél condujo a abusos que se deseaban evitar como el acaparamiento de bienes por parte de la Iglesia. Enfatiza que aun cuando son los eclesiásticos españoles y franceses los más afectados, al determinarse su expulsión del país, los gobiernos de ambos países han reconocido el "derecho pleno y absoluto" de las autoridades mexicanas a actuar de esa manera. 
Al abrir la información del día dedicada a la guerra cristera con esas declaraciones de Alfonso Reyes, la información de L se confronta abiertamente con la de GN. Mientras que ésta reitera en sus titulares los problemas de política exterior que le ha acarriado al gobierno mexicano su postura antirreligiosa (aunque sus textos sólo lo den como una gran probabilidad), L, a través de fuentes oficiales se encarga de desmentir esa posibilidad.

En segundo lugar se publica una nota sobre el complot a Calles y las contradicciones que hay sobre su existencia. Recordemos que esta información, en forma muy confusa, ya había sido publicada un día antes por GN. L advierte que su información proviene de un despacho de Nueva York, en el que se aportan datos tanto sobre la veracidad de tal complot como de que puede ser un invento de un periodista español, quien fue el primero en darlo a conocer a las autoridades.

Como se ha presentado anteriormente en L, se recurre a "personas bien informadas" que "creen" en un hecho dado y de ahí emana el contenido del texto. No se mencionan nombres concretos acerca de la fuente informativa. Este rasgo también es visible en la nota sobre disturbios ("Dicen de Méjico") en Irapuato, población de Guanajuato.

La sustitución de la imagen de la Virgen de Guadalupe y los intentos por sacarla del país son los temas de la siguiente nota publicada en L. La siguiente, sin embargo, no posee la unidad de la que le antecede, ya que toca cuatro asuntos distintos: el rumor de que han muerto protestantes mexicanos a causa de los disturbios en Irapuato, la vigilancia en la frontera con Estados Unidos, la felicitación del arzobispo mexicano a los católicos por su conducta de los últimos días y el que en varios poblados la gente vista de negro, como protesta por los hechos recientes. A pesar de los múltiples temas sobre los que se habla en este texto, su extensión es breve, lo cual condiciona que no se ofrezcan abundantes datos sobre ellos.

Sin embargo, el menos extenso de los cinco escritos publicado por $\mathrm{L}$ ese día es, precisamente, el que origina el titular de esta sección. “¿Un disparo contra Calles?" da cuenta de la información que el Daily Telegraph asienta y que $\mathrm{L}$ recoge. Ésta versa sobre el intento de asesinato que casi dos semanas antes se cometió en contra del presidente mexicano. Llama la atención que se cuestione el hecho en el encabezado, cuando ni en el titular de toda la sección ni en el texto aludido se pongan en duda. Es evidente que L no quería dar por cierto 
el acontecimiento hasta corroborarlo, dado que el caso del complot contra Calles aún no se había aclarado.

Con una diagramación y extensión similar al del día anterior, GN vuelve a situar en primera plana y ocupando un poco más de tres columnas naturales el levantamiento cristero. No obstante, en esta edición apuesta un poco más por el género opinativo, ya que incluye dos textos de esta naturaleza (uno firmado por Miguel Peñaflor y otro sin nombre al calce) y uno más que es una transcripción de un escrito del escritor Charles Maurrás, publicado en L'Action Française.

Se sigue optando por un gran juego tipográfico en el titular ("La inicua persecución religiosa en México da lugar a nuevos y sangrientos sucesos") y los subtítulos, igualmente descriptivos que los aparecidos en otros días. En esta ocasión serán tres: "Los protestantes norteamericanos defienden uno de sus templos, intervienen las tropas y matan a varios, entre ellos a un pastor", "Amigos del gobierno, contando con la pasividad de la policía incendian varias casas", y "El arzobispo de Méjico se dirige desde el destierro a los católicos y les felicita por su valiente actitud frente a la tiranía".

A simple vista podemos darnos cuenta que los cuatro casos que engloban dichos enunciados fueron publicados también ese día por L. Todos ellos se desprenden del pequeño texto que L encabeza escuetamente como "Nuevos disturbios". GN, sin embargo, los separa en distintos textos, aun cuando sean igualmente breves e incluso, los mismos de L (lo cual indica que es información proveniente de alguna agencia informativa, aun cuando no se explicite).

Las detenciones por el complot, la felicitación del arzobispo, la duda sobre el atentado a Calles, los disturbios en Irapuato, y las señales de luto por los sucesos son los hechos que, como L, recoge GN. Las variaciones son mínimas entre uno y otro medio, pero por eso mismo son significativas. Así, los titulares de estas notas son muy sintomáticos: "Sangrientos sucesos", "Detenciones por el complot", "Matando protestantes", "El arzobispo les felicita" y "¿Otro atentado?". Por ejemplo, el tercero de ellos da cuenta del matiz adverso que se desea imprimir a las acciones del gobierno. En esa misma nota se agrega una información que no aparece en L y es sobre la inminencia de la intervención del gobierno estadounidense, "a pesar de los esfuerzos del Ku Kux Klan”. Con anterioridad, en GN ya se había relacionado a Calles con dicho grupo. 
Entre la información que aporta GN y que no fue publicada por L, está el resultado del boicot económico de los católicos sobre todos aquellos productos que le den algún tipo de renta al gobierno (información muy similar a la insertada en ediciones pasadas), la posibilidad de un cambio de la política de Calles (ante supuestas presiones de los gobiernos extranjeros como el de Inglaterra), la autorización de las autoridades mexicanas para que un representante de cada parte entable pláticas para la resolución del conflicto (se retoma otra nota ya publicada sobre el rechazo de un plebiscito, propuesto por el episcopado) y la adhesión a los católicos mexicanos de los creyentes de Brasil, Colombia, Ecuador, Venezuela y Argen-tina.

Como es posible observar, GN fundamenta en algunas plataformas informativas su línea ideológica: la inminencia de la intervención de los gobiernos extranjeros, y específicamente el de Estados Unidos, para terminar con el conflicto; la solidaridad de los católicos de diversas partes del mundo; la voluntad conciliatoria de el clero mexicano que contrasta con la bélica de las autoridades del país; lo sanguinario de la persecución, en donde los más afectados son los católicos; la extensión del problema a otros ámbitos de la sociedad mexicana: economía, educación, tradiciones, etcétera.

La sección titulada "Méjico" es situada por L, el jueves 6 de agosto, en la página dos, con lo que varía la localización que usualmente se le adjudicaba a este problema (la quinta página, dedicada a la información internacional). No obstante, reduce la extensión que le venía destinando en los dos últimos días y aborda el conflicto en sólo tres notas breves.

Bajo el encabezado "El poder civil logra imponer su soberanía", L asienta tres textos que se refieren, únicamente, a declaraciones y acciones llevadas a cabo por el gobierno mexicano. Entre los días anteriores ya analizados, éste es el que más demuestra las simpatías de este medio por la línea de Calles, tanto por la naturaleza de los temas publicados, como por los omitidos, así como por las cabezas empleadas. En todas ellas ("Noticia oficial del complot y atentado contra Calles", "El gobierno logra hacer efectivas las leyes" y "Sólida situación del gobierno") se presenta una imagen de fortaleza de las autoridades civiles mexicanas, en los encabezados más descriptivos empleados hasta ese momento (no perdamos de vista que en días 
anteriores, eran muy concisos y trataban de evitar el empleo de adjetivos calificativos).

Aunque los despachos provienen de París y Nueva York, la información se afirma emanada de envíos telegráficos provenientes de México, de los cuales sólo el relativo al complot contra Calles aporta una fuente específica (el general Álvarez, primer secretario de la presidencia). Las demás se basan en hechos recabados y no en declaraciones.

La primera nota informa sobre el comunicado oficial del atentado en contra de Calles. De acuerdo con la redacción del texto, podemos entrever una inadecuada estrategia de comunicación -en general, respecto al conflicto, pero particularmente en este caso-, ya que se dejó que se corriera el rumor en relación con el intento de asesinar al presidente mexicano. La polarización de opiniones que prevalecía en la época, debido a las polémicas determinaciones del representante del Poder Ejecutivo, favoreció que fuera "negado por muchos escépticos, tanto más por no haberse publicado comunicado oficial alguno", asienta el texto. Esta falta de oportunidad será aprovechada, por ejemplo, por GN, dado que cuestionará la veracidad de lo que se dice en dicho comunicado y será visto como una treta armada para granjearse la simpatía internacional.

El encargado de emitir la información oficial sobre el atentado fue el primer secretario de la presidencia, y da a conocer que se disparó contra el automóvil en el que viajaba Calles, sin que nadie resultara lesionado. No se pudo encontrar al responsable, pero a través de las pesquisas policiales ya se había detenido a una mecanógrafa: Dolores Lemua.

En la segunda nota informativa, L da por hecho, basándose en los despachos noticiosos provenientes de México, que la "victoria será del gobierno". Lo sustenta en que $90 \%$ de las iglesias habían sido cerradas y convertidas en centros cívicos, sin "grandes desórdenes". Se informa sobre algunos disturbios en Tampico y que se ha permitido que unos pocos templos permanezcan abiertos, con el propósito de que la ciudadanía constate que "es posible ir a rezar a los santuarios".

Este texto ilustra dos temas que, de alguna manera, hemos abordado y que se manifestarán en el manejo de la información sobre la rebelión cristera en México: por un lado, la confrontación entre la verdad histórica y la periodística. Se habla del cierre de iglesias sin que hubiera, por ello, grandes problemas, cuando, por los mismos medios 
de comunicación -únicamente basándonos en el análisis de las dos primeras semanas- sabemos de los múltiples enfrentamientos, las decenas de muertos que éstos han provocado, los cientos de heridos, el clima de tensión interna y de expectativa, a nivel internacional, etc. También notamos un optimismo que la historia se encargaría de desmentir, dado que dos semanas después de haber estallado la guerra cristera, se da por hecho que es cuestión de días su conclusión; sin embargo, el problema se alargaría durante dos años más y ecos de éste se prolongarían hasta 1932.

El otro tema que se evidencia, mediante dicha nota informativa, fue denunciado varias veces por GN: la polarización de la prensa mexicana y el apoyo a cada bando, de acuerdo con sus intereses. Que L asiente: "Todos los despachos de Méjico coinciden en afirmar que la victoria será del gobierno" apunta no sólo a una especulación (que, como hemos señalado, fue falsa), sino a una situación que refleja que lo que la prensa mexicana experimentaba era similar a lo que acontecía en la prensa vizcaína. Es decir, L en esta ocasión publica aquello que es acorde con su ideología y lo que, de alguna manera, pudiera servir de respaldo a la causa del gobierno mexicano. Por su parte, hemos tenido oportunidad ya de constatar, GN hace lo mismo -más manifiestamente-, pero respecto de la otra arista del problema: la iglesia católica. Esto se registra, de igual manera, en la prensa mexicana .

La tercera nota "Sólida situación del gobierno" no sólo apoya las observaciones realizadas previamente, sino expresa un hecho atípico -dentro de la información analizada en los días previos- en L. Si bien, este impreso no publica dentro del lapso de la muestra ningún artículo de opinión, a partir de este día (5 de agosto de 1926), comienza a realizar inferencias y a plantearlas dentro de las notas informativas. Así, reconoce que la información proveniente de México es "confusa y contradictoria", pero "parece deducirse que la situación del gobierno es más sólida que en estos últimos días", dice en el primer párrafo.

En el segundo párrafo del texto, mezcla información dada en la notas anteriores tanto del día como de ediciones pasadas (respaldo del expresidente Obregón a Calles, cese de aparatosos incidentes, apertura de algunas iglesias), con el objetivo de avalar su deducción. Sin embargo, el despacho proviene de Nueva York, con lo que es evidente que el corresponsal asignado a esa plaza imbrica los géneros 
periodísticos, a fin de proporcionar información, a falta de hechos sobresalientes para L, en ese día (que se hubieran traducido en notas periodísticas relativas a las acciones de los grupos enfrentados, protagonistas del problema, nuevos ángulos de la situación, etcétera).

En L también encontramos, en este día, una disparidad entre los titulares y sus textos. En aquéllos se da como afirmativo lo que en éstos se plantea como una probabilidad cercana, producto de deducciones de L o de especulaciones de la prensa mexicana. Mediante este procedimiento, se apuesta por lo aparente (que en este caso, bien pudiera ser producto de una manipulación informativa) que no necesariamente se relaciona con la verdad. El resultado es que el contundente titular "El poder civil logra imponer su soberanía" se ve desmentido, al prolongarse decenas de meses más el problema.

El viernes 6 de agosto de 1926, GN despliega el mayor volumen informativo (junto con el día siguiente) sobre la guerra cristera, durante el lapso analizado, en primera plana. Poco más de tres cuartas partes de ésta serán dedicadas a un problema que no acontece en suelo español y en donde prácticamente no hubo un involucramiento directo de ciudadanos españoles en el conflicto. De aquí que, nuevamente, sea necesario resaltar lo sintomático que pudiera ser el gran interés que despertó en GN el enfrentamiento entre gobierno e Iglesia en México.

Hay que precisar, no obstante, que si tanto las ediciones del 6 como del 7 de agosto destinan una extensión similar al problema, el día 7 -además- se insertó información (cuatro notas más) en interiores. Sin embargo, el día 6 merece especial atención, ya que lo acontecido motiva al medio a cubrirlo en una forma distinta a como venía informando a su público lector: echa mano de una mayor variedad de géneros periodísticos. Así, se incluye una extensa entrevista con una religiosa de la orden de María Inmaculada, un artículo editorial, la transcripción de algunos fragmentos de un artículo de opinión del Daily Mail (al que GN le llama “crónica”), y siete notas más sobre el tema.

A lo largo de cuatro columnas se extienden cuatro titulares, cuya jerarquización está dada por el tamaño de la letra, la fuente de la misma y su estilo. El que se asienta, en primer término, es "La masonería honra a Calles, su esclarecido hijo". Le siguen: "Los prelados mejicanos han ocultado a la rapiña bolchevique la venerable imagen de Nuestra Señora de Guadalupe", "Muere en la celda de la cárcel un 
obispo mejicano" y "Lo que nos cuenta una religiosa, víctima del sectarismo mejicano, que acaba de llegar a Bilbao". El sumario que continúa se refiere totalmente a la entrevista, cuyo encabezado es el último de los cuatro. Puede verse también un recuadro central "La única fuerza educadora y civilizadora" que es el que asienta la transcripción del Daily Mail aludida ya, y un titular "Lo lógico parecía..." inserto después de la entrevista y antes de las notas sobre el asunto, que abre el editorial. Dado el diseño de la página, tal parece que tanto el encabezado del artículo como los de las notas son, en realidad, ladillos de la entrevista.

Cinco subtítulos componen el sumario. Cada uno de ellos resalta un aspecto diferente, emanado de la entrevista con la madre María Isidra. El primero da cuenta de la corrupción del presidente mexicano "Doce mil pesos de plumas de avestruz sobre los hombres [sic] de Ernestina I, hija de Calles, ¿sabe?"; "La procesión del averno" es el siguiente, y alude al desfile del carnaval, en donde una carroza representaba, alegóricamente, el infierno; la tercera es "Este convento está bien disfrazado" que, en estilo indirecto libre, recoge las palabras de un inspector del gobierno mexicano respecto de una estratagema empleada por las religiosas para hacerse pasar por profesoras. "Cuarenta luises armados" hace alusión al número de jóvenes que montaban guardia en el convento para proteger a las religiosas de un posible desalojo. "Pretendían casar a un obispo y que los curas se dediquen a otra cosa" es el último sumario que se refiere a las propuestas que se le hicieron al obispo de Tabasco y a varios sacerdotes, con el objeto de que no fueran expulsados del país.

En esta entrevista se plasman algunos hechos que ya habían sido dados a conocer por la prensa vizcaína previamente, y otros de orden anecdótico. Sobre los primeros, la religiosa habla de oídas (que Calles es masón y ha sido condecorado por éstos; que odia a los sacerdotes y a las monjas porque durante 50 años han estado "comiendo el pan de los mejicanos"; que amenazaban al obispo tabasqueño para que contrajera matrimonio y a los sacerdotes para que se dedicaran a otra actividad, etc.), y acerca de los segundos, cuenta lo que ha vivido (vestir de negro, primero, y con ropa de otros colores, después, para no ser reconocida; ser alojada en la casa de una rica señora española; las revisiones por parte del personal del gobierno mexicano para verificar que el convento se había cerrado definitivamente; las celebraciones del carnaval que presenció, en donde la hija de Calles fue la reina; la 
muerte de una compañera de orden, debida a la impresión que sufrió al escuchar lo que acontecía; su salida de México para refugiarse en Bilbao, etcétera).

Los ladillos no coinciden siempre con los subtítulos que componen el sumario. Por ejemplo, uno de ellos es "Alojadas en casas particulares", otro es "El papa envía a Méjico el entredicho", y ninguno figura en dicho sumario. En el primero se refiere a la táctica que se siguió para no ser expulsadas del país. Esto sucedió en casas de buena posición económica (la religiosa habla de "un matrimonio sin hijos que vive con veinte criados"), que incluso actuaban como prestanombres de la Iglesia, con el objeto de que no le expropiaran a ésta sus bienes.

Acudimos, entonces, a una señora española exponiéndole nuestra angustiosa situación y fue tan buena con nosotras que declaró: que el edificio era suyo - está ahora a su nombre- y lo convertimos entonces en escuela técnica para la enseñanza del lavado y planchado.

El último ladillo da pie a una pequeñísima información (la dispensa de aplicar misa, dada la situación en México), antes de dar por concluido el texto. Éste combina el estilo directo, el indirecto y el indirecto libre.

Los primeros párrafos sirven de introducción al lector para darle a conocer quién es la persona que será entrevistada. Acto seguido, se transcriben las preguntas y los comentarios del periodista, así como las respuestas de la madre María Isidra. La inserción del tercer ladillo da la impresión de que se ha cambiado el estilo de la entrevista, dado que al receptor puede parecerle que ya no hay mediación discursiva alguna y que está escuchando el relato de la religiosa de viva voz. No es así, sin embargo, como puede inferirse en la vuelta al procedimiento de pregunta-respuesta, elegido por el redactor. No obstante, a partir del quinto ladillo, el periodista decide omitir sus intervenciones y darle íntegramente la palabra a la entrevistada. Esta técnica prevalecerá justo hasta antes de finalizar el texto, el cual concluye con la explicitación del agradecimiento hacia la religiosa y un comentario de salida.

La postura del reportero puede ser aprehendida por el lector, tanto por los signos explícitos como por los implícitos en su discurso. En sus líneas de apertura, al dirigirse a la entrevistada, dice: "Venimos a que nos cuente usted detalles de la intolerable, por cruel, persecución que han padecido en Méjico" o, al referirse a ella: "una víctima como usted". De esta manera, le comunica tanto al lector como a la 
entrevistada, la postura que tiene sobre el conflicto e induce a la religiosa a adoptar una actitud determinada en sus respuestas (situarla en el papel de perseguida, de víctima, desde antes de que inicien las preguntas).

Al concluir, el periodista asienta: "y damos por terminada nuestra grata entrevista no sin felicitar a la bondadosa Madre María Isidra por haber llegado bien a nuestra villa". Resalta el uso del adjetivo "grata", ya que la narración de la religiosa gira en torno de los apurados momentos que había vivido en los últimos meses. Bien pudiera emplearse para referirse que aceptó contestar a los cuestionamientos, o bien, el adjetivo podría atribuirse a la sensación experimentada por el propio periodista, quien obtuvo la información deseada. Hacia esta hipótesis apuntan las últimas líneas del texto:

... esta curiosa información, que confirma cuanto el cable va diciendo de la bárbara persecución de que son víctimas los católicos.

Hay que recordar que la idea de "bárbara persecución" ha sido repetida en varias ocasiones en $\mathrm{GN}$, desde las primeras noticias y titulares relativos al conflicto. Es decir, de esta manera se plasma cómo el periodista ha acudido a la entrevista con un prejuicio, el cual se ve confirmado -sostiene él- con lo contado por la religiosa.

Un hecho que resalta de este texto es la mención del periódico mexicano Excélsior, el cual -afirma María Isidra- "es un periódico bueno de allí" y cuyo reportero fue amenazado con la cárcel si seguía defendiendo con sus artículos a la jerarquía eclesiástica. Por su parte, el entrevistador externa el juicio de que es más valioso el relato de un testigo presencial "que todos los relatos de la prensa, que pasan por muchas manos..." Este señalamiento es singular, desde dos puntos de vista. El primero de ellos podemos relacionarlo con el epílogo del texto, en donde se confirma la verdad de lo publicado por GN, dado que las palabras de una testigo coinciden con el giro adoptado por el periódico. Lo que no se le evidencia al lector es que la información prodigada proviene de una sola perspectiva, que nunca es contrastada con la información emanada por los contrasujetos protagónicos de los acontecimientos. El segundo señalamiento gira en torno de la situación por la que atraviesa la prensa: antes de ser publicado un texto, ha tenido que realizar un largo recorrido (ser extraído de un medio de comunicación local o extranjero, provenir de una agencia noticiosa -nunca explicitada por $\mathrm{GN}-$, ser fragmentado o ampliado con 
comentarios por parte del periódico vizcaíno, ser censurado previamente por el gobierno mexicano, etc.). De esta manera, el propio reportero sugiere la gran mediación de por medio que marcaba a los medios de comunicación de la época.

Por último, respecto de este texto, deseamos hacer notar cómo los hechos adquieren un matiz determinado, de acuerdo con la óptica con que se plasman discursivamente. De esta manera, un desfile de carnaval se convierte en "La procesión del averno". Cierto es que al permitir que una carroza con una alegoría de esa naturaleza paseara por las calles de la capital mexicana puede ser considerado como una clara provocación, dada las connotaciones que podía insinuar y que fueron aprovechadas por los idéologos de los creyentes. En este mismo hecho, se confunde la realidad con la ficción, al asentar en el sumario "Ernestina I, hija de Calles", sin aclarar que éste fue un título con el que se llamó con motivo de las fiestas del carnaval. Así, no sólo se refuerza la idea de la corrupción de Calles, sino que se consolida el campo semántico que se le ha adjudicado, en cuanto a sus ansias desmedidas de poder, su papel de dictador y, por lo tanto, su semejanza con los gobiernos comunistas. Otro ejemplo sería cómo la propuesta a los religiosos de colgar los hábitos, como una opción para no expulsarlos de México, es teñida con un giro pecaminoso (la religión católica prohibe a sus ministros romper el juramento del celibato).

“¡La única fuerza educadora y civilizadora!” es el título del texto publicado por el Daily Mail y traducido por GN, en virtud de que vale "por muchos artículos y más en periódicos de tal importancia y significación". Al igual que con el artículo del Times y dado a conocer por GN el miércoles 4 de agosto de 1926, se recurre al argumento de autoridad de la prensa extranjera para reforzar el punto de vista del medio local. En esta ocasión no se aclara que sólo han sido publicados fragmentos y se resalta con el uso de mayúsculas y cursivas aquellas palabras o frases que interesan particularmente a GN.

En el artículo traducido ("crónica" para GN), se ensalza la labor de la Iglesia como "la ÚNICA fuerza educadora, caritativa y civilizadora en este país semi-salvaje". El empleo de la mayúscula afirma la noción, enfatizada ya en días anteriores, de que sólo la religión puede oponerse a la barbarie. Observamos, de nuevo, la ratificación de los extremos semánticos civilización vs. barbarie, en donde sólo la fuerza de la Iglesia puede disolver la condición salvaje de los mexicanos. Las 
mayúsculas se repiten con el mismo adjetivo, al referirse a las escuelas religiosas, se dice que eran "la ÚNICA ESPERANZA para la educación primaria del país". Así, la visión que se ofrece es de naturaleza apocalíptica: si se expulsa a los representantes de la religión, la incultura (la barbarie) apresará a México. De esta forma, la Iglesia se ha convertido de redentora de almas a símbolo de cultura, a necesaria presencia en cada uno de los ámbitos de interés social.

También se presentan otros rasgos ya destacados en ediciones previas, como el echar mano de la figura de Porfirio Díaz. El fin de su dictadura es considerada como el principio de "la anarquía" vivida por México en lo que va del siglo. A su inamovilidad en el poder se le resta importancia, pues "aunque era autócrata, era estadista", razón por la cual no puso en vigor las leyes respecto a la Iglesia, promulgadas antes de su ascensión a la presidencia. Por su parte, contrasta el artículo, Plutarco Elías Calles y "su principal lugarteniente Luis Moreno, son más trade-unionistas que políticos", de aquí que sean presas fáciles de los comunistas. De esta manera, Iglesia y capitalismo son unidos en un mismo bloque, en su polarización respecto del socialismo. Esto es apuntalado en el último párrafo, en donde se informa que "Yucatán y Puebla son nidos de bolchevismo" y que el gobierno mexicano ataca a la religión por seguir "las normas de sus maestros de Rusia".

En este punto, se olvida lo que en el mismo texto fue apuntado: las leyes mexicanas habían sido dictadas desde más de 50 años; cuando no se preveía siquiera la revolución de octubre. Ponerlas en vigor, sin embargo, sólo se explica a raíz de la influencia comunista, sin que se deje el resquicio de la duda a la autoderteminación de un gobierno.

Llama la atención que la filiación comunista que se le adjudica a las autoridades mexicanas sólo se transparente a través de la desamortización de los bienes eclesiásticos y la expulsión de la jerarquía eclesiástica. En ninguno de los textos de GN o de los periódicos a los que cita se analizan aspectos relativos a la economía, la educación, el trabajo, etc. O sea, no hay otro elemento que haga temer a los gobiernos extranjeros, Estados Unidos incluido, de un viraje comunista en la política mexicana. ¿Cuál es la razón entonces, de que se identifiquen las acciones de Calles con el comunismo? Muy posiblemente, la adhesión de la opinión pública local y externa en torno de la iglesia católica. Con la identificación del comunismo como generador de horrores múltiples, que lesionan la moral impuesta por la 
época y por las mismas instituciones eclesiásticas, no sólo se incentiva el fervor religioso, sino que se crea una animadversión generalizada por otro tipo de gobierno, distinto al que conocen los países de Europa central y América.

Las otras siete notas breves que aparecen en la edición del 6 de agosto de GN abordan temas varios. La primera, la más extensa de ellas, habla de la sustitución de la venerada imagen de la Virgen de Guadalupe para preservarla de la confiscación de bienes, por parte de las autoridades. Aunque aquí se desarrolla en forma un poco más amplia, este hecho también es dado a conocer ese día por L. El gran parecido de ambas notas permite que sus discrepancias enfaticen las diferencias ideológicas de ambos medios.

Entre lo que publica L y GN, varían algunas palabras, por ejemplo: GN dice "La muchedumbre de fieles" y L, "Los fieles". Con la eliminación del sustantivo, L reduce la dimensión del fervor católico en la ciudad de México y, específicamente, por la virgen de Guadalupe. $Y$ viceversa, ya que al no contar con el despacho original, no estamos en condiciones de afirmar cuál de los dos periódicos agrega u omite. Vemos, sin embargo, que L se caracteriza por la brevedad y la concisión, en tanto que GN por la abundancia de su información. Así, L suprime un pequeño párrafo, en el que GN aventura la posibilidad de desórdenes por el reemplazo de la imagen; el corte sensacionalista de GN así como su interés por destacar la gran oposición a las medidas gubernamentales, se manifiesta de manera inversa en L: no alude éste, hechos que pudieran expresar animadversión en contra de las autoridades o bien, los minimiza, en su estilo conciso y contenido. De esta forma, tampoco asienta, como GN, que los prelados que escondieron la imagen están dispuestos a no revelar el sitio "ni aun por salvar la vida", porque de esta manera caracterizaría a los sacerdotes de la misma manera que GN: como víctimas, dispuestas a que su vida les sea arrancada por el bárbaro gobierno mexicano.

En una información brevísima (cuatro líneas de una columna) de GN, proveniente de París, "Se dice que la Federación Mexicana de Cámaras de Comercio ha adoptado la resolución de oponerse al boicotaje de los católicos". Esto se opone a las continuas menciones de este medio de que la economía mexicana se vendría abajo, dada la decisión de los creyentes de no acudir a los comercios, como muestra de su repudio a la puesta en marcha de las leyes antieclesiásticas. 
La nota que versa sobre la detención de tres obispos es enviada desde Nueva York e inicia como muchos de los textos de GN: con una introducción que habla de ánimos exacerbados, mediante el empleo de adjetivos y sustantivos que pueden ser considerados de índole superlativa (excitación "enorme", "gran sensación”, "enérgica protesta", "acto valeroso"), si se les compara con los hechos a los que aluden. Al igual que en otras ocasiones, el título que encabeza la nota se refiere al último hecho relatado. El primero se refiere a la formación de un comité superior integrado por católicos, para defender su religión a través de la resistencia.

"Censura rigurosa" regresa a otros temas ya mencionados en días anteriores: impedimento de formación de grupos alrededor de las iglesias y supresión de todo aquello relacionado con la religión.

“IIntervienen los Estados Unidos?” es el título de la siguiente nota que difícilmente podría inferirse de lo expresado en ella, ya que se comunica que en "todas" las iglesias católicas neoyorquinas (de esta ciudad proviene el despacho) se ruega por los creyentes mexicanos, la reducción drástica en el número de sacerdotes que permanecen en México, la posibilidad de que el Vaticano fungiera como mediador en el conflicto, la "enérgica" protesta del cónsul general de los EUA por la incautación de un templo protestante y la recomendación del presidente de este país de conservar "la más absoluta neutralidad". El lector, entonces, bien pudiera cuestionar el origen del encabezado, si el mismo Coolidge habla de neutralidad y no de intervención. Ésta, en todo caso según podría extraerse de la nota, sería por parte del Vaticano y no del vecino mexicano del norte.

"Los soviets se aprovechan" es una información extraída del periódico parisino Le Matin. En ésta se hace hincapié de la idea de los soviets de enfrentar a México con Estados Unidos, aprovechando el "odio que todo mejicano alienta contra" este país. Así, por una parte, GN justifica -a través de la publicación de sus escritos- una intervención del gobierno de EUA, pero sin que ésta se convierta en motivo para que el comunismo apoye al país latinoamericano. Es evidente, pues, que el argumento de las ideas comunistas existentes detrás de las decisiones de Calles esté cimentado en el afán de atemorizar a los lectores, y no porque fuera un hecho.

Como podemos ver, la información vertida por GN el viernes 6 de agosto de 1926 destaca por varios rasgos: la variedad de géneros 
periodísticos con que aborda el conflicto cristero; la reiteración de acontecimientos, cuya inserción no agrega nada nuevo a lo que ya se conocía sobre este problema (pero que funciona eficazmente entre los lectores, en el sentido de que, a fuerza de repeticiones, lo dudoso puede convertirse en algo cierto); la discrepancia entre los titulares y sus textos. Esto no es sólo evidente en las breves notas publicadas, sino también entre los titulares y el contenido general del escrito (por ejemplo, se habla de la muerte de un obispo mexicano en una celda y, en cambio, en ninguno de los textos se aborda este hecho; o bien, el primer titular que se destaca es la última noticia, según el orden de aparición).

El sábado 7 de agosto, después de tres días de no incluir notas sobre el conflicto cristero en interiores (ya que empleaba únicamente la primera plana), GN publica cuatro textos en la sección "Última Hora", ubicada en la tercera página del impreso. Dos de ellos motivan su inclusión dentro de los titulares de la columna ("Aprovechan la incautación de las iglesias en México para robarlas" y "Los Caballeros de Colón piden al presidente Coolidge que intervenga") y todas provienen de París.

El primer texto (cuyo título es "Iglesias robadas"), que figura dentro de los titulares de la sección, es de apenas tres oraciones muy breves: "Aumenta la alarma con motivo de las incautaciones de las iglesias. De muchas de ellas han desaparecido objetos de valor. Los autores de los robos gozan de impunidad." En éste observamos carencia de concreción (¿en cuántas iglesias han desaparecido objetos de valor?, ¿qué tipo de objetos son éstos?, ¿cómo se supo de su robo?, ¿quiénes son los autores?, ¿qué argumentan las autoridades al respecto?), ya que no proporciona datos que aporten al lector elementos informativos específicos.

"Los Caballeros de Colón" es la siguiente nota (incluida también entre los titulares de "Última Hora") breve que señala que esta organización ("la más potente" en Norteamérica) ha pedido a Coolidge que no ayude al gobierno mexicano y que exija respeto "a los ciudadanos yanquis católicos, para quienes ha tenido desprecios o injurias".

Los disturbios ocurridos en la ciudad de México, que tuvieron un saldo de dos muertos y 15 heridos, son el tema del siguiente texto, titulado "En el templo de Guadalupe". Esta cabeza tiene su origen en 
que en dicho lugar acontecieron los desórdenes, propiciados por la resistencia de los católicos a que fuera cerrado el recinto más venerado del país. Esta corta nota no está exenta del empleo de adjetivos ("muy graves sucesos", "extraordinaria veneración", "ruda batalla"), dirigidos a resaltar la magnitud del suceso y la creencia firme de los católicos, dispuestos a sacrificarse por sus ideas (ellos se "opusieron tenazmente" a que el templo fuera "secuestrado").

La última nota, de apenas una oración, lleva por título "Sacerdote excomulgado". Este suceso se debió a que se declaró "partidario de las reglas religiosas del gobierno".

El sábado 7 de agosto, por su parte, L ofrece información sobre el conflicto tanto en la portada como en páginas interiores. El caso de la primera plana ya había sido observado el 1 de agosto, pero en esta ocasión es especialmente relevante porque se trata de un artículo de opinión que va acompañado por una llamativa foto del presidente mexicano Plutarco Elías Calles. Durante los días incluidos en la muestra analizada, éste fue el único en donde L insertó una imagen relativa al conflicto cristero; lo hizo, además, en forma destacada: en la parte central superior (el espacio ocupado por la tercera y cuarta columnas) del periódico, con titular y pie.

La cabeza de la foto reza un escueto: "Plutarco Calles" y muestra una imagen de busto de esta autoridad mexicana. La seriedad del fotografiado se ve acompañada por el siguiente pie: "El presidente de la república de Méjico que con serena energía está logrando someter al clero a las leyes de la nación". De esta forma, L continúa proyectando el mensaje que desde días anteriores había venido repitiendo en sus titulares: lo controlado de la situación y la firmeza de la decisión presidencial (sobre la cual se hace hincapié en la cabeza de ese mismo día, en la información localizada en las páginas interiores). Al acompañar el sustantivo "energía" con el adjetivo "serena", no sólo alivia la contundencia de la palabra, sino que actúa como un elemento que equilibra la información sobre las cuantiosas muertes producidas por los enfrentamientos entre soldados y creyentes. La "serena energía" del presidente, así, no es la causa de tantas pérdidas humanas, sino el fanatismo, las acciones impulsivas de la contraparte.

El texto que acompaña a esta fotografía, por tratarse de un artículo de opinión, será analizado en el siguiente apartado. Sin embargo, podemos adelantar que imagen y escrito se complementan a la 
perfección: si la cabeza de la fotografía es el nombre del presidente, la del mensaje opinativo es "Los religiosos en Méjico". De esta forma, se trata de transmitir el punto de vista sobre los dos protagonistas del conflicto.

Ese mismo día, L en su segunda página (que usualmente no se destina para información internacional, sino local) cabecea cinco textos, con el título "Calles, sigue firme". Como podremos constatar, una vez que hablemos de cada una de las notas que integran esta información, el titular encara con ambigüedad lo desarrollado en la edición de ese día.

Por una parte, puede verse que L coincide con GN en publicar dos datos: El primero de ellos es el anuncio de la excomunión del sacerdote por declararse partidario de la nueva reglamentación religiosa. Como GN, L no ofrece más detalles; incluso, ni siquiera le otorga un lugar preferencial y lo integra a otro tema, cuyo titular es "Respuesta al presidente de Perú". Sobre esto se dice que Calles le contestó al presidente peruano que seguirá adelante con la aplicación de la nueva ley religiosa. De esta información puede desprenderse el titular general ("Calles sigue firme"), cuya ambigüedad bien puede sugerir firmeza en cuanto a su propia posición dentro del gobierno mexicano o, como hace referencia la nota, a su propósito de llevar a cabo las medidas antieclesiásticas.

A pesar de que la siguiente nota alude a una petición de los Caballeros de Colón al presidente Coolidge y es del mismo día que la publicada por GN, tal pareciera que nos encontramos ante dos informaciones distintas. L es contundente al asentar cuál es la petición de los Caballeros de Colón: anular el reconocimiento del gobierno de Calles y exportar armas a México (GN habla de no ayudar a las autoridades mexicanas y exigir respeto hacia los ciudadanos "yanquis"). GN no da a conocer la respuesta de Coolidge y L, sí; ésta gira en torno de que no se tomarán "tales medidas mientras los intereses americanos no sean perjudicados". No sabemos, sin embargo, si ésta es tomada de lo publicado por GN un día antes (en donde se afirmaba que Coolidge se pronunciaba por la neutralidad) o si verdaderamente es una respuesta a la petición de dicha organización.

La inclusión de la nota "El clero de Méjico" es interesante, dentro del tipo de textos que venía publicando L. Es una de las pocas que son extraídas de otros medios periodísticos; en este caso, de un periódico 
de Berlín, cuyo corresponsal investigó los sueldos de las altas autoridades eclesiásticas mexicanas, así como el número de sacerdotes, frailes, religiosas y parroquias. No obstante, L se abstiene de realizar comentario alguno sobre estos datos y sólo los introduce refiriéndose a ellos como "interesantes detalles".

"Actitud de los protestantes" proviene de un envío de Londres que da cuenta de la marcha normal de todas las iglesias protestantes que se han comprometido a "observar escrupulosamente" las leyes religiosas del país. De aquí que las autorides hayan devuelto al rector de la iglesia protestante episcopal de San José el templo del mismo nombre.

Desde Washington, L recibió el texto "Posición del gabinete de Washington", que retoma el tema de la petición de los Caballeros de Colón (abordado ese mismo día) y aunque es un poco más larga, básicamente expresa lo mismo: la decisión del gobierno de Estados Unidos de defender los derechos de los ciudadanos de su país establecidos en México, pero de no intervenir en la política interior del Estado mexicano.

El último día de la muestra analizada, 8 de agosto de 1926, GN reduce el volumen total de información publicada, respecto a los días anteriores (el espacio destinado es comparable al inserto el 3 de ese mes), pero sigue destinando tanto la primera plana como la sección "Últimas Noticias" para dar cuenta de lo que sucede en México.

Tres titulares abren la información de la primera plana y su jerarquización (de arriba hacia abajo) coincide con el tamaño del tipo elegido. Así, "L'Osservatore romano y la política de Calles" es la cabeza que más destaca, seguida por "El rector de la Universidad de Lima elogia la admirable y desinteresada labor de los misioneros españoles en América" y "Estados Unidos vigila los movimientos militares y el desarrollo de la cuestión económica en México". Éstos abrirán los 10 textos que integran el total de la información incluida en la portada del día.

"Una conferencia interesante" es la primera de las noticias incluidas en la información de la portada y es igual de reducida que otras cinco insertas en ese mismo lugar: "A la expectativa", "Cardenal secretario", "No va con los protestantes”, “¿Desea pactar?” y "Seis muertos en Guadalajara". Proveniente de México, la que abre la información del día da cuenta de la reunión sostenida por el obispo de Tabasco y el fiscal general, aunque no se brindan más datos al respecto. El titular, 
entonces, se convierte en una opinión del periódico, puesto que el texto no aporta elementos para decidir acerca del interés del encuentro.

"A la expectativa" resume una nota del New York Herald, despachada desde Washington. Uno de los reiterados mensajes de GN (la disposición del gobierno estadounidense de intervenir en el conflicto) vuelve a aparecer, como explicación de la orden recibida por el servicio de inmigración de vigilar la frontera. "Cardenal secretario" habla sobre el regreso del secretario de Estado de la Santa Sede, después de haberse tomado unos días de descanso "con motivo de la situación de México". Ello, porque monseñor Crespi (refugiado en Estados Unidos, como fue informado en una edición anterior) "constantemente" le entera de cuanto sucede en ese país. La devolución de un templo protestante (publicada un día antes por L) es el tema de "No va con los protestantes", titular que en su formulación refuerza la idea de encono en contra de los católicos. Se omite la información dada por L acerca de la aceptación de la jerarquía protestante de cumplir las leyes mexicanas puestas en vigor.

Sin revelar la fuente, “¿Desea pactar?” alude al deseo de Calles de encontrar una solución: él solicitaría que las autoridades católicas cesaran su resistencia y, a cambio, liberaría a los detenidos y dejaría entrar al país a algunos de los sacerdotes expulsados. Esto contrasta con "algunos telegramas" recibidos por GN, en torno de la postura "totalmente irreductible" del presidente, señala la nota. El último de los textos breves de la portada aborda los enfrentamientos ocurridos en Guadalajara y el saldo de muertos que han dejado.

Los otros cuatro escritos que conforman la información de la portada son ligeramente de mayor extensión que los anteriores $\mathrm{y}$, como éstos, provienen de despachos de distintos lugares del mundo (Washington, México, París, Roma). "Los efectos comerciales en Norteamérica" tiene como tema el impacto que en ese rubro puede tener la situación en México, sobre todo porque EUA teme un descenso en las importaciones de automóviles y artículos de lujo, base del intercambio mercantil con su país vecino. La actitud del Ministerio de Comercio es la de acopiar información y mantenerse a la expectativa.

"Periódicos suspendidos" es el titular de un texto que no alude este tema sino en sus últimas líneas. En las primeras, se habla de la recomendación de Calles a los gobernadores de las entidades federativas del país de que se observen las disposiciones dictadas en 
torno de la cuestión religiosa. Se alude también a los rumores en el interior del país de que el presidente ha sido asesinado y que son los católicos quienes están al frente del país. Por último, se informa sobre la suspensión de dos periódicos de Puebla, debido a que dieron a conocer, falsamente, la huida del gobierno a Veracruz (puerto mexicano desde el cual salían los buques hacia el extranjero).

"La obra de los misioneros" es el texto que da pie a uno de los titulares de la portada. Alude a la declaración efectuada por el rector de la Universidad de Lima acerca de la "admirable y desinteresada labor" de aquéllos en América y cómo, por ello, "Méjico les debe su civilización". En el apartado dedicado a los artículos de opinión nos detenemos en la dicotomía civilización-barbarie, sin embargo, podemos observar que forma parte de las ideas que constantemente manejara GN, en los textos informativos y de manera destacada en los titulares, los sumarios y los subtítulos. De acuerdo con los plantemientos que GN efectúa, a la civilización sólo se llega a través del catolicismo y cuando éste es regulado, como en el caso mexicano, crece la barbarie, en una relación inversamente proporcional. Para sostener esto, apela a los juicios de autoridad. En este caso es el rector de una universidad. Si el cargo académico no bastara, el medio realiza una presentación que sirve de aval a sus declaraciones; dice de él que es "uno de los hombres más eminentes de la América del Sur", además de "ilustre peruano". Incluso, es posible reconocer que "Se puede hablar mal de la obra política de España", pero no de la labor de sus misioneros. Así, la nueva colonización en América debe verse ya no en términos de poderío militar, de autoridad civil, sino en términos ideológicos a cargo de la Iglesia católica.

GN reproduce algunos fragmentos de un artículo publicado por L'Osservatore Romano, en el último de los cuatro textos de mayor extensión de los asentados en la portada. En él, el medio que funge como vocero del Vaticano examina el contenido del artículo 130 de la Constitución de los Estados Unidos Mexicanos. Este análisis constituye una respuesta al comunicado enviado por el gobierno mexicano sobre la naturaleza de dicha ley. L'Osservatore Romano llega a la conclusión de que el artículo 130 no trata de separar a la Iglesia del Estado, "sino de lo contrario" (ya que la Iglesia tenía que inscribir a sus ministros, las autoridades gubernamentales autorizarlos y comunicárselos). La lógica en la que descansa este razonamiento es 
el vínculo de tipo administrativo que unía a ambas entidades, por lo que no se puede hablar de una separación real entre una y otra.

Al igual que el día anterior, GN -el 8 de agosto- también proporciona información sobre el tema, tanto en su primera plana como en interiores, en su sección "Última Hora". En esta ocasión, sólo se publica una nota, pero que por la importancia que se le asigna también figura entre los titulares de la sección ("La situación en Guadalajara (Méjico) es grave"). Veamos cómo, ante la especificación del lugar donde ocurren los acontecimientos, GN ve la necesidad de aclarar de qué país se está hablando.

En este texto se da el saldo de dos enfrentamientos acaecidos en Guadalajara, a partir de un despacho girado desde París. En ambos casos se asienta la cifra de católicos muertos (cinco en el primero y dos en el segundo), pero no se mencionan las posibles bajas entre los soldados, el otro bando al que se enfrentaron. Se dice la cantidad exacta de detenidos (416 personas), entre las que se cuentan "varias personalidades de gran relieve en la ciudad y algunas distinguidas señoras".

Parece ser que ésta es la misma nota que aparece en la portada de GN, titulada "Seis muertos en Guadalajara", pues el número de fallecidos es similar (siete en "Última Hora"), las condiciones son parecidas (enfrentamiento entre soldados y católicos) así como el lugar (Guadalajara).

El último día de la muestra analizada, el 8 de agosto de 1926, L publica cinco notas, en su sección "Lo de Méjico", ubicada, en esta ocasión, en la tercera página. Cuatro de ellas también fueron dadas a conocer por GN ese mismo día, con titulares muy distintos y, como también se ha visto en otras ediciones, textos modificados por añadidos o modificaciones.

El primero de los artículos es cabeceado: "Manifestaciones de un diplomático norteamericano". Éste recoge las opiniones del diplomático "que ha residido largo tiempo en Méjico y ha estudiado a fondo la situación política y religiosa del país". Como GN, en el caso del rector de la universidad de Lima, L respalda su línea editorial a través de las palabras de una aparente autoridad en el tema, aunque no especifica quién es, tampoco cómo se consiguió la información (si ésta es tomada de algún otro medio, si es una entrevista, etc.). Al ser la única información que difiere de las publicadas el 8 de agosto por GN 
adquiere una relevancia significativa, ya que marca un punto de vista que interesa a L, por lo que ha buscado o, por lo menos, no ha sido omitido (como pudiera haber sido el caso de GN).

El desconocido declarante opina que la irritación del pueblo mexicano se ha debido al estrecho vínculo que existe entre el alto clero (de origen español y francés, principalmente) y una poderosa oligarquía, de la cual forma parte "una mayoría de antiguos propietarios españoles". En realidad, sostiene, es ésta la que está utilizando a la Iglesia católica como medida de presión para que el presidente Calles acepte sus condiciones.

"Actitud de Calles" es una de las notas incluidas por L que también aparecen ese día en GN. En ella funde lo que GN aborda en sus textos titulados "Periódicos suspendidos” y “¿Desea pactar?”, ya que L da a conocer tanto la decisión de Calles de seguir adelante con la ejecución del artículo 130 como la revelación de una "persona adicta al gobierno" de que éste desea pactar con la Iglesia. La última parte de la nota es la que aparece en "Periódicos suspendidos" y se refiere a la recomendación de Calles a los gobernadores de los estados de México de que observen las disposiciones puestas en marcha, no admitan "la manifestación externa de ningún culto público" y prohíban "cualquier manifestación política, aun las de adhesión al gobierno".

El movimiento envolvente que se observa en esta nota es de gran interés, ya que primero se habla de la firmeza de la decisión de Calles, luego de su posibilidad de que pacte con la Iglesia (lo cual debilitaría la imagen enérgica y convencida proyectada en el primer párrafo del texto), y por último sobre su llamado a que se cumplan estrictamente las leyes. De esta forma, sin explicitarlo, se atenúa el efecto de la segunda información. De aquí que la "Actitud de Calles" a la que alude la cabeza de la nota no sea de búsqueda de una solución concertada, sino de cumplimiento a las leyes mexicanas.

"Noticias falsas" publica el mismo cable que GN tituló como "Periódicos suspendidos". El contenido es básicamente el mismo (sólo que L omite el rumor de que Calles hubiera huido a Veracruz), pero el acento que se pone en los titulares favorece un cambio de óptica. Así, GN enfatiza la suspensión de los periódicos, debida a la publicación de esa falsa información, mientras que $\mathrm{L}$ recalca la causa de dicha sanción. L, así, titula de acuerdo con el orden de importancia atribuida a la nota, según su orden de aparición (recordemos que el dato de la 
suspensión a los impresos de Puebla era el último en aparecer en GN, a pesar de ser el que cabeceaba el texto).

"Cómo se ve la cuestión en el Vaticano" es exactamente el mismo texto inserto en su portada por GN. Varía, como es de suponerse, el titular. En GN se alude a las dos partes en conflicto, mientras que en el de L el hincapié está puesto en el punto de vista de las autoridades religiosas. De esta manera, L aligera el peso que pudiera tener lo expuesto en la nota, al proponerlo como tan sólo una de las posibles versiones acerca del tema. No perdamos de vista que GN, por otra parte, cabecea toda la información sobre el conflicto, localizada en su portada, aludiendo precisamente a esta nota. L, por su lado, no aporta ningún elemento diferenciador respecto a las demás que publica ese día, lo que trasluce que no tiene interés alguno por destacarla por encima de las otras cuatro.

"Declaraciones de un obispo" es el texto que cierra la información del día y que también es dado por GN en su edición del 8 de agosto. Da a conocer el número de muertos que hubo, a raíz de un enfrentamiento entre soldados y católicos, en los alrededores de la Villa de Guadalupe, así como el de los decesos ocurridos en otro disturbio en las afueras de una capilla. El declarante es el obispo Díaz, quien añade que también hubo bajas por parte del ejército, pero no proporciona el número exacto, en ninguno de los dos casos. Como ya es usual en este tipo de notas, la información proviene de México: "según noticias de Méjico", pero es enviada desde Londres.

\section{Conclusiones}

A lo largo de este trabajo hemos tocado dos aspectos principalmente: uno formal y otro respecto al contenido de los textos publicados. Ambos han sido de gran utilidad para poder contestar las preguntas que nos planteamos desde el inicio de este análisis, dado que mediante la forma (espacio concedido, tipo y extensión de los titulares, inserción en una página determinada, texto de naturaleza informativa u opinativa, etc.) cómo se dio a conocer la guerra cristera en el País Vasco podemos deducir el efecto que se deseaba producir en los receptores del medio. Mediante el análisis de los contenidos no sólo ratificamos la tendencia ideológica de la publicación, sino también la caracterización que se conforma sobre los protagonistas de los sucesos, la relación de lo informado respecto a lo que realmente aconteció (según los historiadores), y el grado de interés que un hecho tan lejano 
geográficamente despertó en la prensa vasca y los posibles motivos para que así ocurriera.

De acuerdo con el análisis formal efectuado, podemos concluir que:

a) La Gaceta del Norte le dedica un espacio mucho más vasto a la guerra cristera en México que El Liberal. Mientras que la primera, en los 15 primeros días del conflicto, cubre un total de 315 páginas y el segundo 145. No obstante, los hechos cubiertos son semejantes. La diferencia estriba en la publicación de artículos de opinión de GN, la transcripción de algunos fragmentos de ese mismo género de otros periódicos, o la inclusión de declaraciones de fuentes eclesiásticas, mientras que L opta por dar a conocer más acontecimientos que opiniones o declaraciones.

b) La importancia de la necesidad de difundir la guerra cristera propicia que GN le adjudique una dimensión magnificada, en relación con la óptica de L, según lo demuestra el número de apariciones en portada. No obstante, no hay que confundir esta necesidad de difusión con la importancia periodística del problema, ya que esta última es entendida por El Liberal, dado que crea una sección especial dedicada al conflicto cristero.

c) Los titulares de GN suelen ser más largos y más explícitos que los de L. Éste suele obviar el lugar donde acaecen los sucesos y procura subsanarlo con el antetítulo o el nombre de la sección ("Lo de Méjico"). Sin embargo, en la misma denominación de este apartado se trasluce cómo se da por hecho que los lectores han seguido el conflicto desde sus inicios. Con ello, coincidimos con Ofa Bezunartea (1990: 164), quien afirma que los diarios de los años treinta "estaban hechos para lectores habituales, enterados y acostumbrados a leer el periódico íntegramente". De aquí que en ninguna nota se retomen los antecedentes del problema, con excepción de algunas redundancias acerca de lo que entrañaban las llamadas "leyes anticlericales". Pero hasta en este caso, se repiten los mismos tópicos (incautación de bienes, sobre todo) y no se alude a otros renglones contemplados por ese mismo artículo constitucional.

d) Tanto en los titulares como en los textos de sus notas y el artículo de opinión publicado, GN recurre frecuentemente a la generalización ("Todo el mundo se alzará contra la barbarie persecutoria mejicana", "En todas las iglesias católicas de esta ciudad se celebraron solemnes rogativas (...)", "La Iglesia ha sido la ÚNICA fuerza educadora, 
caritativa y civilizadora en este país semi-salvaje"). Éste es un caso del empleo de las falacias (expresiones que aparentan argumentarse en la lógica), en donde mediante la retórica a la que se acude se trata de impregnar de objetividad el texto.

e) Hay una gran dependencia hacia los despachos informativos que provienen de París, Londres, Roma o Washington, sobre todo en el caso de GN. Esto podría explicar las ocasiones en las que se registra un retraso de 24 horas, en relación con la información ya dada a conocer por L. Este dato, además, contribuye a darnos una idea de las fuentes de donde provenía el flujo informativo en Europa, en esos años.

f) GN juega con los distintos tipos de letra y cuerpos en sus titulares, con el objetivo de enfatizar algún significado. De esta forma, se observa una mediación formal en relación con el contenido del titular (ya de por sí claramente dirigido ideológicamente). En su diseño, L muestra una mayor consistencia en el uso de la tipografía y tamaño de los titulares. No así en lo que se refiere a la maquetación, ya que GN suele ser más constante en la correlación sección/página, en relación con L. De esta forma, GN destina la portada o la sección "Última Hora" para los textos relativos al conflicto cristero, mientras que L los envia a portada, segunda, tercera o quinta páginas.

g) Es mayor la variedad de géneros periodísticos con que GN se refiere al conflicto que L. Mientras que este medio se limita a transmitir los hechos a través de notas, generalmente del tipo de los breves informativos, y un solo artículo de opinión, GN amplía sus procedimientos discursivos a través de la inclusión de artículos de opinión, híbridos, donde mezcla éstos con textos informativos, entrevistas y notas.

En cuanto al análisis de contenido:

a) La lejanía geográfica y cultural entre los países, España y México incrementa la dificultad de pronunciación y/o de escritura que presentan las palabras de origen indígena. Así, términos provenientes del náhuatl como Nochixtlan o vocablos recurrentes en la topografía mexicana como Aguascalientes provocarán indecisión ortográfica al asentarlos (Nóchixtlan, Nochixtlán, Nochistan o Nochixtlan; Pacheco o Paseco; Aguas Calientes).

b) Es frecuente la omisión o la no especificación de las fuentes ("se cree", "dicen que", "los católicos están decididos"). Éste es otro recurso retórico a través del cual el medio de comunicación disfraza los 
matices subjetivos, confiriéndoselos a una colectividad anónima, la cual no puede desmentir, ni protestar, dado que no hay un informante específico, un origen determinado de los datos aportados.

Cuando se recurre a las citas, las de GN suelen ser de los representantes de asociaciones católicas o autoridades eclesiásticas (en el caso en que se citen fuentes cercanas al gobierno mexicano, son puestas en duda o ironizadas, a través de distintos recursos ortográficos o gramaticales). Las fuentes de L cubren un espectro más amplio, aunque le dan más voz a las del gobierno mexicano.

Por otra parte, GN suele apoyarse en lo publicado por otros medios, como garantía de que su punto de vista es generalizado. Así, reproducirá fragmentos del Times londinense, del Daily Mail, el Examine o citará otros como el Journal des Debats, Le Matin, The New York Herald, etc., en una clara apelación al argumento de autoridad.

c) La información no siempre es constatada, sobre todo durante la primera semana del conflicto: se basa en rumores, en lo asentado por la prensa local, diarios de París, de Estados Unidos o en datos no confirmados. Esto favorece que el manejo de la información pueda ser formulada en los términos que ideológicamente más convengan a la publicación. Es decir, hay tanta mediación entre el hecho y lo que finalmente se publica, que aquél pierde importancia frente al interés de que al receptor le llegue un mensaje determinado.

d) Por el tratamiento de la información, GN polariza el problema entre católicos y no creyentes. Como católicos abarca a los sacerdotes, seminaristas y jerarcas eclesiásticos, fieles. En la categoría de los no creyentes, GN engloba al gobierno y ejército mexicano, los masones (unas veces; otras, "francmasones"), los socialistas, los bolcheviques, los sectarios.

e) Las mujeres desempeñan un papel protagonista: son víctimas de la situación (peregrinan descalzas, son latigueadas), pero también ejercen una función activa: declaran, son representantes de asociaciones, se enfrentan a las autoridades, una de ellas es "alma del complot" contra Calles, y otras siete son arrestadas por el mismo motivo, apedrean a las tropas, escriben cartas a las autoridades, dimiten de sus puestos porque tienen nombramiento oficial, participan en mítines en forma multitudinaria (en favor del gobierno), etc. Es decir, toman partido, sea adhiriéndose a la causa cristera, sea a la del gobierno (A.A.V.V., 1985: 373). 
f) GN y L difieren en la manera como titulan sus textos. GN enfatiza el cariz violento de la situación (en 15 de sus 19 notas hay algún verbo, adjetivo o sustantivo que así lo indica), o sea, en casi 79\% del total de la información (ver anexo 1). L presenta este matiz en siete de sus 17 textos; es decir, en $41 \%$ de ellos (ver anexo 2). El hincapié de quiénes son las víctimas de la violencia, también varía, dado que en GN, en todos los casos son los católicos; en L, o son los representantes del gobierno (el presidente Calles, un alcalde) o no se especifica (en titulares como "Más muertos y heridos" o "En México han ocurrido luchas sangrientas").

g) Aún cuando L y GN cubren todos los mismos acontecimientos en varias ocasiones, el lector -si las contrasta-podría tener la impresión de que se encuentra ante dos hechos completamente diferentes. El tipo de comentarios incluidos, la puntuación, pequeñas omisiones o añadidos cambian sustancialmente el contenido de la información (como en el caso de la protesta de Inglaterra por la incautación de una iglesia episcopal, o de la sustitución de la imagen de la virgen guadalupana).

h) Los titulares de ambos periódicos no siempre corresponden a la importancia de la información que transmiten sus textos. Esto acontece, sobre todo, cuando se encabeza con un dato que aparece sólo hasta el final de la nota, o bien, cuando el titular parcializa el contenido total (por ejemplo, alude sólo a un hecho de otros dos o tres distintos de los que también se abordan). Sin embargo, GN recurre a este procedimiento en forma mucho más frecuente que $\mathrm{L}$.

i) En ocasiones, las tendencias ideológicas de cada medio propician su alejamiento de lo que acontece realmente, tal y como lo demuestra la confrontación de los ejemplares periodísticos con las investigaciones de corte histórico.

j) GN presenta la tendencia de mezclar los rasgos del género periodístico opinativo con el informativo. Sin ningún tipo de marca tipográfica, se pasa de una nota informativa a un artículo de opinión, dentro del mismo texto. De esta manera se difumina el hecho respecto a la valoración.

Las observaciones anteriores nos permiten decir que la actitud de Calles es tomada como un intento de descolonización ideológica: la Iglesia católica, como un cúmulo de creencias importadas de Europa, no tuvo oposición significativa alguna (con excepción de las Leyes de 
Reforma de la época juarista, en el último cuarto del siglo pasado), ni por parte de la sociedad ni por el lado gubernamental. No se trataba tan sólo de una confrontación de ideas, sino también de intereses económicos. Situación motivada también por la ambición de la nueva clase política mexicana, que vio en ésta una oportunidad para sacar provecho de los bienes desajenados a las instituciones eclesiásticas.

El tratamiento informativo no sólo trasluce la ideología de cada medio, sino también se inserta en un proceso más complejo. La lucha de los cristeros en México puede verse como un paradigma que luego se reproducirá, con sus variantes naturales, durante la II república y la guerra civil en el Estado español. El empleo de encabezados de tipo propagandístico, la información de hechos que no acaecieron como se plantean, la no difusión de otros que sí acontecieron, son sólo algunas de las técnicas empleadas por la prensa vasca, durante la guerra civil española, que ya se detectan en 1926 en las informaciones sobre la guerra cristera mexicana.

\section{Bibliohemerografía}

A.A.V.V. (1985), Crónica del siglo XX, Barcelona: Plaza \& Janés.

Abril Vargas, Natividad (1994), "Las mujeres en la prensa diaria vasca", en Protagonistas temáticos, tratamiento periodístico, Bilbao: UPV.

Almuiño Fernández, Celso (1990), "Proceso a la prensa vasca (1936-1939). La Inquisición franquista y la formación de la causa general", en Comunicación, cultura y política durante la II república y la guerra civil, t. I, País Vasco (1931-1939), Bilbao: UPV.

Bardin, Laurence (1986), Análisis de contenido, Madrid: Akal.

Beyhaut, Gustavo y Hélène (1986), América Latina. III. De la independencia a la Segunda Guerra Mundial, 2a. ed., Madrid: Siglo XXI.

Bezunartea Valencia, Ofa (1990), "Acontecimiento, conocimiento ciudadano e historia: el test del 19 de julio", en Comunicación, cultura y política durante la ll república y la guerra civil, t. I, País Vasco (1931- 1939), Bilbao: UPV.

Castro Ricalde, Maricruz (1998), "Ideología y artículos de opinión” en Revista Académica, no. 3, Toluca: ITESM.

Dorselaer, Jaime y Alfonso Gregory (1962), La urbanización en América Latina, 2 t., Madrid: Siglo XXI.

Estornés Lasa, Bernardo (dir.) (1988), Enciclopedia general ilustrada del País Vasco. Diccionario enciclopédico Vasco, San Sebastián: Auñamendi.

Garitaonandía, Carmelo (1988), La prensa y la guerra de ondas en Euskadi (1936-1937), s/l : s/e.

Gran Enciclopedia Larousse (1970), vols. III, VII, Barcelona: Planeta.

Jensen Klaus, Bruhn (1992), La semiótica social de la comunicación de masas, Barcelona: Bosh Comunication. 
Krippendorff, Klaus (1990), Metodología de análisis de contenido. Teoría y práctica, Barcelona: Paidós.

Lerchundi, Alberto (1985), La Gaceta del Norte. 83 años de historia, Bilbao:UPV.

(1985a), La Gaceta del Norte (1901-1984). Muerte ideológica de un diario" en La prensa de los siglos XIX y XX. Metodología, ideología e información. Aspectos económicos y tecnológicos, Bilbao: UPV.

López Aranguren, Eduardo (1992), "El análisis de contenido", en El análisis de la realidad social, métodos y técnicas de investigación, Madrid: Alianza Editorial.

Ruiz de Gauna Lucas, Adolfo (1990), "Catálogo de publicaciones periódicas vascas en la Guerra Civil (19 de julio de 1936-1 de abril de 1939)" en Comunicación, cultura y política durante la II República y la Guerra Civil. Tomo I. País Vasco (1931-1939), Bilbao: UPV.

Sánchez Aranda, J. J. Barrera del Barrio, C. (1992), Historia del periodismo español, desde sus orígenes hasta 1975, Pamplona: EUNSA.

Xamardo, Nicolás (1986), “Argumentación y retórica en un artículo de 'El Anunciador Victoriano"' en La prensa de los siglos XIX y XX. Metodología, ideología e información. Aspectos económicos y tecnológicos, Bilbao: UPV. 